Illinois State University

ISU ReD: Research and eData

Theses and Dissertations

$6-20-2017$

\title{
"But She's Snow White, She Wouldn't Hurt Anybody": A Critical Analysis of Gender and Power in Once Upon a Time
}

Mackenzie Mahler

Illinois State University, mackenziemahler@gmail.com

Follow this and additional works at: https://ir.library.illinoisstate.edu/etd

Part of the Mass Communication Commons

\section{Recommended Citation}

Mahler, Mackenzie, "'But She's Snow White, She Wouldn't Hurt Anybody": A Critical Analysis of Gender and Power in Once Upon a Time" (2017). Theses and Dissertations. 763.

https://ir.library.illinoisstate.edu/etd/763

This Thesis is brought to you for free and open access by ISU ReD: Research and eData. It has been accepted for inclusion in Theses and Dissertations by an authorized administrator of ISU ReD: Research and eData. For more information, please contact ISUReD@ilstu.edu. 


\title{
“BUT SHE'S SNOW WHITE, SHE WOULDN'T HURT ANYBODY”: A CRITICAL ANALYSIS OF GENDER AND POWER IN ONCE UPON A TIME
}

\author{
Mackenzie Mahler
}

\section{Pages}

This thesis examines gender performance and its relation to power in the television series Once Upon a Time (OUAT). On the surface, OUAT is a television show that constantly challenges the culturally-ingrained gender norms often found in fairy tales, as it creates new storylines for traditional fairy tales. This warrants a deeper examination of the series to understand if and how it is subverting these typical gender norms. To fully understand how gender operates in $O U A T$, I examined how gender affects and is affected by hegemony in the show and how this relates to our cultural understanding of gender and power. Using the narrative paradigm as a lens, I examined two character arcs for six different characters to determine the relationship between power and gender in the series. I found that $O U A T$ actually reinforces hegemonic gender norms through regulation of appearance, traits and skills, and unequal distribution of power.

KEYWORDS: Once Upon a Time; gender; media; television 


\section{“BUT SHE'S SNOW WHITE, SHE WOULDN'T HURT ANYBODY”: A CRITICAL}

ANALYSIS OF GENDER AND POWER IN ONCE UPON A TIME

MACKENZIE MAHLER

A Thesis Submitted in Partial Fulfillment of the Requirements for the Degree of

MASTER OF SCIENCE

School of Communication

ILLINOIS STATE UNIVERSITY 
Copyright 2017 Mackenzie Mahler 
“BUT SHE'S SNOW WHITE, SHE WOULDN'T HURT ANYBODY”: A CRITICAL ANALYSIS OF GENDER AND POWER IN ONCE UPON A TIME

MACKENZIE MAHLER

COMMITTEE MEMBERS:

Phil Chidester, Chair

K. Megan Hopper

Lauren Bratslavsky 


\section{ACKNOWLEDGMENTS}

First, I would like to thank my chair, Dr. Chidester, for being beyond patient with me throughout this process. Your quick feedback and constant positivity have helped me stay motivated to do my very best work. I would also like to thank my committee members, Dr. Hopper and Dr. Bratslavsky, for your continued support and help in the writing of this document. Thank you to Lindsey for allowing me to bounce all of my ideas off of you and continuing to listen even as the stress drove me insane.

Thank you to Melissa for pushing me to continue on even when I felt I couldn't. You have given me so much support and kindness, and I could not have done it without you. Also, thank you to Kat, CJ, and Chet for keeping me company while I wrote and for being the perfect distraction when I needed it.

Finally, I would like to thank the School of Communication at Illinois State University for allowing me to learn from the best and guiding me through this process.

M. M. 


\section{CONTENTS}

$\begin{array}{lr} & \text { Page } \\ \text { ACKNOWLEDGMENTS } & \text { i } \\ \text { CONTENTS } & \text { ii }\end{array}$

CHAPTER I: PROJECT INTRODUCTION 1

$\begin{array}{ll}\text { Project Rationale } & 1\end{array}$

Gender in Society $\quad 2$

$\begin{array}{ll}\text { Fairy Tale and Myth } & 4\end{array}$

$\begin{array}{ll}\text { Gender and Disney } & 7\end{array}$

Gender in Popular Television $\quad 9$

$\begin{array}{ll}\text { Once Upon a Time } & 11\end{array}$

$\begin{array}{ll}\text { Method } & 12\end{array}$

$\begin{array}{ll}\text { Narrative Paradigm } & 12\end{array}$

Once Upon a Time 13

$\begin{array}{ll}\text { Characters } & 13\end{array}$

$\begin{array}{ll}\text { Analysis Process } & 14\end{array}$

$\begin{array}{ll}\text { Thesis Preview } & 15\end{array}$

CHAPTER II: LITERATURE REVIEW 16

Gender in Society 16

$\begin{array}{ll}\text { Fairy Tale and Myth } & 19\end{array}$

$\begin{array}{ll}\text { Gender and Disney } & 25\end{array}$

$\begin{array}{ll}\text { Gender in Popular Television } & 28\end{array}$

$\begin{array}{ll}\text { Once Upon a Time } & 30\end{array}$ 
Narrative Paradigm

Once Upon a Time

Characters

Emma Swan

Henry Mills

Mary Margaret/Snow White

David/Prince Charming

Regina Mills/The Evil Queen

Mr. Gold/Rumplestiltskin

Analysis Process

Characters

Emma Swan

Henry Mills

Mary Margaret/Snow White

David Nolan/Prince Charming

Regina Mills/Evil Queen

Rumplestiltskin/Mr. Gold

Appearance

Traits and Skills

Power Differences

Conclusion 
CHAPTER V: DISCUSSION

$\begin{array}{ll}\text { REFERENCES } & 100\end{array}$

APPENDIX: CHARACTER DESCRIPTIONS 


\section{CHAPTER I: PROJECT INTRODUCTION}

\section{Project Rationale}

When people ask me why I study what I study, I often joke that my goal is to make a job out of watching Netflix. The reality is that rhetorical criticism allows me to engage with the media that I love in new and exciting ways. This is why I decided to study the rhetoric of one of my favorite television shows, Once Upon a Time (OUAT). Specifically, I have explored the gender portrayal of characters in $O U A T$ and whether or not this modern show has been able to transcend the hegemonic patriarchal ideology from classic tales. I examined both female and male characters to understand how gender is enacted and regulated throughout the series, but before I elaborate further on this this, it is essential to understand why I chose this as my project.

Television has been an integral part of my life since I was a child. While I loved doing other activities like reading, I also loved getting lost in a movie or television show. TV always differed from books and movies because it was more of a living entity than the others, constantly evolving before my eyes. Watching TV has never been just one hour a night devoted to my favorite shows. Instead, I become involved in the storylines, and I feel personally invested in different characters' lives. I read fan theories and fan fiction to see how others interpreted the same work in such a different manner than I did.

These parasocial relationships became more complex as I grew (Schiappa, Allen, \& Gregg, 2007). In college I became very civically engaged and active in my community. I was becoming more aware of social inequalities and how society operates in a way that keeps an oppressed group in a subordinate position. My focus has been primarily on issues that affect me, such as gender inequality and the oppression of LGBTQ individuals, but I am also interested in studying race and other cultural inequalities. Learning about social justice and critical theory 
soon became one of my passions, and this filtered over to every aspect of my life, including media consumption. I vividly remember watching a movie with friends and being appalled at how problematic the depiction of mental illness and gender were, but they did not see the issue with it. It was just a movie, after all. At this same time, I was enrolled in my first rhetorical criticism course, and I was finally able to conduct research that combined my passions of learning about individuals, analyzing different media like TV, and identifying problematic aspects of society that most people blindly accept.

I specifically chose $O U A T$, a television show on $\mathrm{ABC}$, as my text for my thesis because of its rich history, appeal to viewers, and feuding fandom. OUAT brings classic fairy tales into a modern society. The series takes place in a small town in Maine, where all of the fictional characters from Fairy Tale Land have been displaced after the Evil Queen - Snow White's rival casts a curse to end all happy endings (ABC, n.d.). This show is rooted in fairy tales that have been told for generations, but it shares these stories in a completely different way, weaving the tales together to create a completely different universe. While many of these classic fairy tales have been studied at length in previous research, the re-invention of them calls for updated research. It also allows for these tales to be retold for a modern audience, one that deals with diversity and oppression more directly and frequently than previous audiences. This was a very intriguing aspect of the show for me, and I could not help but think of at least a dozen different ways to research this show.

\section{Gender in Society}

As I am analyzing $O U A T$ for its portrayal of gender, I believe it is important to briefly make a distinction between sex and gender, as the two are often conflated in research. Sex usually refers to the biological sex of an individual, usually indicated by their chromosomes 
(Butler, 2006; Mills \& Mullany, 2011). Gender is typically not biological, although some argue otherwise, but a social construct regulating behavior (Butler, 2006). The difference between the two is notable because the definition for gender is a lot more abstract than sex and can take on different definitions. Looking at gender through different viewpoints and philosophies will help produce the best understanding of gender within $O U A T$ and how it differs between characters and settings.

There are three main ways that scholars typically view gender: a biological difference, a social difference, or a cultural difference (Butler, 2006). Most scholars focus on the social and cultural differences between genders. While some theorists view gender as being culturally assigned (i.e., a part of an individual's identity), this view has been criticized when looking at fixing gender inequalities in society. Instead of seeing gender through an essentialist viewpoint, other theorists, such as Butler, view gender as being performative. This "performance" is not an act or a false display of one's self, but it is a series a gender behaviors that an individual performs based on societal expectation (Butler, 2006). Gender performance is not something that individuals are actually aware of doing. Gender performance is so expected and so normalized in society that it becomes second nature, which acts as a regulating and limiting force (Butler, 2006; Mills \& Mullany, 2011).

Foucault also critiques the essentialist view of sex and gender in which gender is an identity. Much like Butler, Foucault believes that gender is a socially constructed experience (Butler, 2006; Foucault, 1978; McNay 1992). Unlike other scholars, Foucault rejects the biological definition assigned to sex because it is used as a means of regulation of individuals rather than individuals regulating sex (Foucault, 1978; McNay, 1992). The idea of sex being used as a regulatory force has inspired feminist research, but that does not mean it is without 
criticism. The main criticism this view faces is that it tends to see sex and gender as equally constricting to both men and women (McNay, 1992). Ignoring male privilege or the oppression that women have faced for centuries means ignoring important aspects of gender and how it is regulated, making it harder to deregulate.

Ignoring the power of personal experience has similar consequences. Women have learned to communicate in new ways about their oppression, as language has historically been created for and by men. Creating these new avenues of communication has allowed women to validate their experiences and work together to combat oppression (Hemmings, 2011; Mills \& Mullany, 2011). Even with these critiques, Foucault presented a new way to examine sex and gender that helped individuals understand how power and regulatory forces are used to keep women in a subordinate position. For the purposes of this paper, I will be drawing on many views of gender, which will be explained in more detail in Chapter 2, and how gender inequality can be presented in a postmodern age through the media.

\section{Fairy Tale and Myth}

Analyzing $O U A T$ requires a deeper understanding of fairy tales and how they operate in a mythic sense. Myths are ever present in society because of their essential role in teaching individuals how to correctly function in society (Campbell, 1973; Rowland, 1990). Myths do this in a few different ways. They offer a solution to the larger problems of society that seem impossible to solve, and they inform individuals about cultural truths that are essential to being successful in a given culture.

Some scholars do not view fairy tales as an important part of myth. While Rowland (1990) does not even believe fairy tales qualify as myth, Campbell (1991) sees them as myth but specifically for children. Fairy tales do not carry the same importance as other mythic tales to 
these scholars, but they both overlook a very important aspect of fairy tales. Fairy tales are often the first mythic tales in which people are introduced, and these stories lay the groundwork for all other myths. Without fairy tales, it would be difficult to learn and understand the importance of more complex myths. Fairy tales also teach important moral lessons about the most basic and essential societal norms.

In addition to these important lessons crafted in mythic form for children, fairy tales have gone beyond a simple child's tale. They are constantly being re-imagined and retold as generation after generation grows up. Some tales, like $O U A T$, are created for an adult audience as well. I cannot agree with Rowland and Campbell that these tales have little lasting impact on an audience because they are entertaining. Instead, I contend that fairy tales should be examined as a type of myth, as they inform their audiences of social truths as well as have a lasting impact, especially on modern cultures.

Gender also plays an important role in mythic tales. Campbell (1991) believes that only men occupy the position of mythic heroes. Women are primarily a secondary character to the male hero, whether they act as a supporting figure, a distraction, or a goal of the journey (Murdock, 1990). Not everyone agrees with Campbell's view of women's role in mythic stories. Murdock (1990) directly challenged Campbell by creating an alternate framework for female heroes called the heroine's journey. She did this because of her experience counseling women and learning of their unique struggles as women. Murdock (1990) believes that women can and do occupy the role of mythic hero, but these mythic tales may not look the same as the ones that Campbell and Rowland describe.

Murdock's (1990) description of the heroine's journey is similar to the hero's journey that Campbell (1973) outlined. The general pattern of separation from the known reality, 
initiation into the supernatural realm, and return to reality is still very present in the heroine's journey. One of the main difference is in the definition of a hero. Murdock (1990) believes that anyone who goes on a journey of some kind can be labelled a hero. This is very different from Campbell (1973), who believes a true mythic hero is inherently different than the average man, endowed with some exceptional abilities. This alteration to the definition is significant because it allows individuals to become a hero through the transformation or rebirth they experience on the journey rather than already containing the essence of a hero.

While this broader definition of hero could potentially be problematic within mythic studies, I think it is the perfect lens for $O U A T$, as the series is a composite of countless different fairy tales and myths that all come together to create one larger story. This means that several characters could fulfill the requirements of "hero" beyond just the main characters. In addition to this, the series itself uses the term "hero" to describe anyone that is working toward defeating some sort of evil. Because of this loose definition of "hero" in the series, I think it is appropriate to use the same sort of language to both further discuss the nature of fairy tales and to examine OUAT.

When discussing fairy tales in further depth, it is essential to first discuss Grimms' fairy tales, a collection of tales created by the Grimm brothers. These tales are largely the inspiration for the more common Disney tales that are also used in OUAT. In most fairy tales, especially that of the Grimm brothers, women typically occupy the role of the hero or the villain. Both female heroes and villains are portrayed very differently from male heroes or villains, even if they share similar traits. For example, humility is a common characteristic of the heroes in these tales, but as the men seem to be born with this trait, the women must learn humility through the course of their story from particularly shameful experiences (Tatar, 2003). Men are expected to 
be more action-oriented than women, among other things. Many of these differences have to do with the inherent patriarchal nature of fairy tales.

The traits of female villains also cater to the patriarchal nature of fairy tales. Female villains tend to be less maternal and have access to more power in Grimms' fairy tales (Tatar, 2003). These tales often define what a good mother is and then put the female villains in direct contrast with that definition. It is also important to note that female villains are women that also possess some sort of power that does not lie in the domestic realm. They have autonomy and the ability to create an impact on society. By depicting these women as evil villains, the stories help reinforce the patriarchal norms present in society.

It is important to examine gender in fairy tales because fairy tales shape our understanding from a very young age. Fairy tales provide us with a framework of how to operate in society, from outlining moral ideals and societal norms to empowering individuals to rise up against injustice (Dewan, 2016; Ward, 2002). Essentially, fairy tales provide a template for understanding good and evil in the world and how to act in accordance with those beliefs. This can become problematic if the ideals and norms being presented are outdated and oppressive. For example, if $O U A T$ is perpetuating a patriarchal ideology or glossing over the subtleties of sex and gender, the show is doing little to challenge the sexism in society and instead actually strengthens the notion that women should not wield power.

\section{Gender and Disney}

OUAT is a television series on $\mathrm{ABC}$, which is a part of the larger Disney franchise.

Because of this, it is essential to understand Disney's take on heroes and villains and the role that gender plays. Disney is practically synonymous with fairy tales, as it has created one of the largest and most profitable empires from its many different portrayals of these stories. As the 
foremost authority on fairy tales, Disney has the unique power to decide what values and ideals to emphasize in its stories, creating and reinforcing the societal truths that we learn from fairy tales (Brockus, 2004; Lacroix, 2004; Ward, 2002). The sheer impact of Disney tales has spurred countless research on the subject, including several book collections just looking at the company's animated films (Bell, Haas, \& Sells, 1995; Cheu, 2013; Lacroix, 2004; Ward, 2002).

To fully understand how gender operates within the good versus evil framework in OUAT, we must first examine how it operates in Disney tales, as $O U A T$ is a Disney creation. Much like the Grimm brothers' tales, there is a clear difference in male heroes and female heroes. Male heroes tend to be more active and egocentric whereas female heroes tend to be more passive and sympathetic (Hoerrner, 1996; Kuykendal \& Sturm, 2007). As women are typically seen as good and pure entities, it makes sense that they would steer clear of more action-oriented activities, like fighting, in favor of more passive activities like listening to others with compassion and sympathy. Female heroes are allowed a certain amount of power in Disney tales, but they are expected to take care in the way they use their power to be sure not to use it in excess (Rozario, 2004). This falls in line with the expectation that women be more submissive and maternal than men, as there are no such expectations for male heroes.

There are other expectations for male heroes, however. Male heroes in Disney tales tend to fit the masculine ideal in society, including broad shoulders, rippling muscles, and a seemingly heterosexual lifestyle (Putnam, 2013; Sattar, 2016). Female heroes do much the same with the feminine ideal. Between the ballet-like movements and the delicate animation, female heroes are seen prancing around while doing tasks often associated with the female gender, like housework (Bell, 1995; Henke, Umble, \& Smith, 1996; Sattar, 2016). Some may think this is only the case with early Disney movies, but aside from some superficial changes, female heroes 
are still very much in line with the feminine ideal (Henke, Umble \& Smith, 1996; Lacroix, 2004; Sattar, 2016). This is significant because several recent Disney productions - OUAT included have attempted to lift women out of the submissive and passive roles from the past, but if these heroes are still being portrayed as the original feminine ideal, however veiled, the company is failing in its attempts and continues to send a message to its audience of what is expected of women.

It is just as important to examine Disney villains and how their gender is depicted as it is to examine the heroes. Just like Disney heroes, male and female villains differ throughout the different tales. There is one similarity between the two, however. In most Disney films, the villain seems to take on traits or appearances that are typically reserved for the opposite gender. In other words, male villains are feminized whereas female villains are masculinized (Putnam, 2013: Sattar, 2016). This is a stark contrast to the heroes of Disney tales, who epitomize what it means to be male or female. In addition to being more gender fluid, female villains have the added element of being far more sexual. Although female villains tend to be more sexual in their actions, in appearance, they are seen as very undesirable (Bell, 1995; Carretero-González \& Rodriguez-Martin, 2009; Sattar, 2016). This makes female sexuality seem inherently bad as it is only depicted in evil, undesirable women. Good women are seen as more innocent and pure than their evil counterparts, highlighting the importance of these qualities in women.

\section{Gender in Popular Television}

Although it is important to examine how Disney depicts gender, it is also important to look at how gender is depicted in popular television. Sexism is largely veiled in most modern television shows. By this, I mean that it is difficult to see the sexism by just looking at a television show on the surface. Instead, the sexism becomes apparent through patterns and 
interactions between characters. This is likely a product of the postfeminist world where feminism and its original goals seem outdated (Munford \& Waters, 2014). Prior feminist activists have made blatant sexism taboo enough that an audience will not accept it. Although blatant sexism is not seen much in television shows today, veiled or covert sexism is still present. This makes sense considering media often mirror society, and both women on television and in the media struggle with the oppressive notions of a patriarchal society (van Zoonen, 1994).

Much like real women, mediated women are confined in certain areas. Women are constantly negotiating their gender identity with the expected gender norms (Morgan, 2007). A great example of this can be seen in a character like Jill Taylor from Home Improvement who seem to fulfill feminist ideals on the surface by seeming more independent and autonomous than other housewives, but even these characters are subject to covert sexism (Dellinger-Pate \& Aden, 1999). Home Improvement is just one example of many that depict their lead female characters in such a way. Even shows that follow lesbian characters tend to still revolve around men in some way (Moritz, 2004).

Women in modern television shows are not immune from falling into the same patterns as female characters in fairy tales, either. Law and Order: Special Victims Unit (SVU) is a notable example of this. Focusing a crime drama on violence against women is a relatively novel concept, especially considering that the subject of violence against women has arguably only recently been acknowledged as a problem. The issues with $S V U$ arise when examining female criminals in the series. These characters fall into the same gender portrayals as villains in the age-old fairy tales (Cuklanz \& Moorti, 2006). If a contemporary crime drama series still pulls from older tales in their characterization of gender, is it possible for $O U A T$, which pulls directly from these older tales for their stories, to transcend these problematic portrayals? 
While there has been an abundance of research on how women have been depicted in television, there is also research concerning the gender portrayal of men. There is a specific brand of hegemonic masculinity that is present in countless television shows and advertisements (Feasey, 2008; Henson \& Parameswaran, 2008). A shining example of this promotion of hegemonic masculinity is the promotional materials for Old Spice. Old Spice commercials are famous for their hyper-masculine mascot that encourages men to become more like him (Kluch, 2015). This can be just as problematic for men as sexism is for women, as it acts as a confining and constraining force on gender expression. OUAT is a television show with a female character as the lead and "knight in shining armor," essentially flipping a traditional gender role. It is important to see how the television show does this and if it actually accomplishes the feat or if it is like many other media that still perpetuates hegemonic patriarchal ideology in a more covert fashion.

\section{Once Upon a Time}

With the large cast of characters, blend of traditional and new tales, and live action filming, OUAT is overflowing with the potential to learn more about the impact of fairy tales on modern culture. While the show has been studied by some scholars, not many have looked at gender throughout the series. Much of the research has examined magical elements or how these fairy tales encourage a loyal audience, something that is very characteristic of $O U A T$ (Hay \& Baxter, 2014; Schwabe, 2014; Wells-Lassagne, 2015). While each of these studies have their own merit, none look at the importance of gender performance throughout the television show, how it connects to past tales, and how it may resonate with an audience. Thus, I examine $O U A T$ further and explain how this series performs gender through different characters and the different implications it may have. 
RQ: Does $O U A T$ change the gender and power dynamics of a traditional fairy tale or does it reinforce the hegemonic patriarchal ideologies found in traditional fairy tales?

\section{Method}

\section{Narrative Paradigm}

Narratives are more than just stories someone tells. According to Fisher (1984; 1985), narratives are forms of persuasive arguments. People learn through stories and are persuaded when these stories make sense and relate to their lives. I chose this lens for my analysis specifically because of how applicable it is to OUAT. The show uses stories known for their ability to inform an audience about social ideals and morals to captivate an audience week after week (Ward, 2002). Narratives are quite impactful on their own with the ability to create and reinforce social realities, but the most impactful and persuasive narratives are myths (Fisher, 1984). This supports what Campbell $(1973 ; 1991)$ and Rowland (1990) claim is the function of myth.

Because narratives are such powerful tools in society in creating and relating social truths, it is important to examine the narrative of gender in media and how that relates to our understanding and expectations of gender. In the narrative paradigm, characters act as symbols of the larger story (Fisher, 1984). The characters in $O U A T$ clearly symbolize moral truths, as the characters themselves are often labeled "good" or "evil" throughout the series. Examining how these characters perform gender can help us understand what $O U A T$ deems good or bad for each gender. Through this idea of symbolization, I examine characters in $O U A T$ and the gender and power dynamics unique to each character. Through this analysis, I hope to learn if and how OUAT has separated itself from previous iterations of these same fairy tales in regards to gender and what that means for its audience. 


\section{Once Upon a Time}

As mentioned previously, $O U A T$ is a television series about fairy tale characters stuck in a small town in Maine with no memory of their previous lives and identities (ABC, n.d.). All of the characters are first introduced in our "real world." The show then incorporates flashbacks to their fairy tale personas so the audience can better understand the true story and motivations behind each character. This means that most of the characters have two separate personas - one "real world" and one fairy tale. OUAT takes classic fairy tales and integrates the story lines to create one cohesive narrative. Although the series alters the tales that we're used to, they make a conscious effort to keep the fairy tale mentality, citing hope as the main theme throughout the series (ABC, n.d.). I will discuss $O U A T$, its fans, and its background in more depth in Chapter 3.

\section{Characters}

Instead of analyzing particular episodes or story arcs, as might be expected with such a project, I have examined particular characters. I chose this method of examination over the others because I feel as though it makes the most sense when looking closely at gender. Gender is not something easily seen in particular episodes or story arcs; rather, gender is connected to the characters themselves and can best be seen when looking at the character's existence as a whole rather than snapshots of said existence.

I have chosen several characters at the forefront of the series that I believe will provide an excellent representation of the series as a whole. I have specifically chosen these characters because they create three distinct dyads. By this, I mean that each dyad consists of characters that are very similar in how they act, their motivations, and how much power they hold in society, and they each consist of one male and one female. These three dyads are also introduced in the show very differently. The "good" dyad is comprised of Mary Margaret/Snow 
White and David/Prince Charming, as they are introduced as the heroes in FTL. The "evil" dyad is comprised of Regina/Evil Queen and Gold/Rumplestiltskin, as they are introduced as the villains in FTL. The "neutral" dyad is comprised of Emma Swan and Henry Mills, as these characters are not introduced in FTL but are strictly situated in the real world, which does not have the same conception of good vs. evil. The good vs. evil dichotomy is clearest in FTL but quickly becomes a fluid entity, much like gender. I am interested to see how each character negotiates their gender after being originally marked as good, evil, or neither and how this affects their access to power. I will explain these characters in depth in Chapter 3, but more information on the characters can also be found in the Appendix.

\section{Analysis Process}

As I have analyzed several characters and the overall societies in the show, it is important to understand exactly what I was looking at to form conclusions regarding gender. When I examined the separate characters, I looked closely at specific story arcs rather than episodes to get a clearer understanding of who each character is and how they evolve throughout the show. A story arc is different than an episode because it typically spans over several episodes (sometimes for as long as a whole season) and brings a particular character into the forefront of the series to deal with a compelling problem. I examined two story arcs per character to fully explore how they negotiate gender throughout the series.

When analyzing these arcs, I looked at things such as costuming, communication with other characters, rise/fall from power, parental instincts, and motivation behind actions, among other things. I also examined how each character interacts with their dyad counterpart to more fully see how gender is reinforced and how power is negotiated by similar characters of the opposite sex. I compared the gendered representations from FTL and the representations in 
Storybrooke for each character, as the two personas are represented very differently. After I examined each character, I synthesized my results for a better understanding of gender in $O U A T$ as a whole and the messages the show is sending to its audience. In Chapter 4, I analyzed the six characters and synthesize my findings.

\section{Thesis Preview}

For Chapter 2 of my thesis, I explored in more detail the existing research on gender, fairy tales, and gender in media. I examined masculinity more fully in this chapter as well. In Chapter 3 of my thesis, I outlined my method in more detail, identifying the story arcs I followed for each character. In Chapter 4 of my thesis, I explored the show for themes regarding gender through a rhetorical analysis of the characters in the show, and I found three distinct patterns in how the show portrays gender. First, the characters perform gender through their appearance. Second, they also perform gender through their character traits and actions. Last, power and control almost exclusively lie with the male characters. In the final chapter of my thesis, Chapter 5, I summarized my findings and discuss the broader implications of these findings as well as potential future research. 


\section{CHAPTER II: LITERATURE REVIEW}

Gender inequality is not a new concept by any means. In fact, it has been a part of an ongoing discussion for centuries. This discourse regarding gender has given us a critical lens to examine society and help improve any inequalities that still exist. I hope to continue the discussion of gender while examining the television show OUAT. Some media, specifically television shows, have attempted to portray women in a less stereotypical light. While this is not always successful, there are also some TV shows that attempt to empower young women (Cuklanz \& Moorti, 2006; Dellinger-Pate \& Aden, 1999; Munford \& Waters, 2014). I will be examining gender in $O U A T$ because this show should be doing just that, with their female lead literally saving an entire population of fairy tale creatures. On the surface, OUAT is a television show that constantly challenges the culturally-ingrained gender norms often found in fairy tales. This warrants a deeper examination of the series to understand if and how it is subverting these typical gender norms. To fully understand how gender operates in $O U A T$, I will be examining how gender affects and is affected by hegemony in the show and how this relates to our cultural understanding of gender and power.

\section{Gender in Society}

Before examining these things, it is important to first understand what gender is and how it operates in our society. When understanding gender and its importance in $O U A T$, it is first essential to define "gender" and how it is different than "sex." "Sex" is often referred to as the biological difference between male and female, often seen in one's DNA or genitalia (Butler, 2006; Mills \& Mullany, 2011). Typically, sex has been seen as a strict binary between male and female, but we know that is not always the case because there are individuals that do not fit into either category. Researchers have begun to question if sex is, in fact, culturally constructed 
(Butler, 2006; Mills \& Mullany, 2011). "Gender" is not biological. It is a concept constructed by society that regulates how someone assigned to a particular sex should behave (Butler, 2006). Gender is masculine and feminine, but it is also more than that. There has been much debate among theorists on what exactly "gender" is and how it operates.

Depending on who you read, gender can be one of many things. I want to look at all of the different sides of gender to determine how exactly it operates throughout the television show. Looking at gender through different viewpoints and philosophies will help produce the best understanding of gender within $O U A T$ and how it differs between characters and settings. Gender can be viewed as a biological difference, a social difference, or a cultural difference (Butler, 2006). Most scholars focus on the social and cultural differences between genders. Some theorists view gender as something that is culturally assigned to individuals - something that they are (McNay, 1992). This view has been critiqued when exploring solutions to rectify inequalities that stem from gender. If gender is something that people are, it cannot be changed. The only solution would be to teach both men and women to value the feminine (McNay, 1992). According to this perspective on gender, women would not be free from the societal expectations that go along with being feminine (i.e., domestic work, child rearing, etc.). Instead, they would be expected to continue doing this work and enjoy it because it is an essential part of their being.

The essentialist view of gender is problematic to some theorists, such as Butler (2006). Instead of gender being something that is intrinsically related to sex, Butler views gender as being performative. She views gender as a result of repeated acts of gender due to societal expectation (Butler, 2006). She notes that gender performance is a not conscious phenomenon. Instead, gender performance is so deeply ingrained in society that "gender" becomes a belief that individuals continue to perform without realizing it; individuals are regulated and constrained by 
gender performance (Butler, 2006; Mills \& Mullany, 2011). Butler's works highlight a clear difference between biological sex and socially-constructed gender. This distinction can also become problematic, however. Butler (2006) notes that if gender becomes a construct completely independent of sex, it ignores the fact that bodies are also sexed through discourse and the effect of such discourse on the body.

Foucault also critiques the essentialist view of sex and gender. He is very careful in his understanding of sex/gender to not separate the two, however. Foucault understands sex as a socially constructed concept that is used to keep particular power structures in place (Butler, 2006; Foucault, 1978; McNay 1992). He rejects the biological definition assigned to sex by most feminist theorists. This is because sex and sexuality are used to regulate individuals rather than individuals regulating sex (Foucault, 1978; McNay, 1992). The idea of sex being used as a regulatory force is a novel one that has inspired feminist research, but that does not mean it is without criticism. Some of the main critiques of Foucault's view of sex/gender is that he largely leaves out the gender side in his discussions; he also does not put much weight on the power of personal experience. Invoking "gender blindness" is problematic because some believe it assumes that men and women are equally affected by sex and its regulatory force (McNay, 1992, p. 33). By this, I mean that men and women experience their sex differently and are regulated by their sex differently. For example, men are expected to be heterosexual, macho, and exhibit fewer emotions. Their actions are determined and limited by society's interpretation of their sex. Rather than dictating what a man can look like or do, men are regulated by the predetermined notions of what their sex should be. The same is true for women.

Ignoring the power of personal experience has similar consequences. Telling tales of their experiences allows women to communicate about their oppression in their own words 
rather than those created by men; this allows women to identify common sites of oppression and work together to subvert the oppressive forces (Hemmings, 2011; Mills \& Mullany, 2011). Even with these critiques, Foucault presented a new way to examine sex and gender that helped individuals understand how power and regulatory forces are used to keep women in a subordinate position. For the purposes of this paper, I will be drawing on many views of gender and how gender inequality can be presented in a postmodern age through the media.

\section{Fairy Tale and Myth}

Before exploring how gender operates in $O U A T$, it is important to note how gender functions in both myth and modern media. First, I will examine how gender functions in myth and fairy tale. Then, I will discuss the research on how gender is portrayed in modern television shows. Finally, I will examine the numerous studies on gender in Disney films, as $O U A T$ is both a part of the Disney franchise and draws directly from many of the popularized tales.

Myths and fairy tales continue to be distributed through popular media even though some of these tales are centuries old. Campbell (1973) argues that myth is present in every society, in every century since mankind could tell stories because of their important function. Although it is nearly impossible to find a common definition of myth, most theorists see myth as a conduit for understanding societal truths (Campbell, 1973; Rowland, 1990). Myths offer a solution to the larger problems of society that seem impossible to solve, and they inform individuals about cultural truths that are essential to being successful in a given culture.

Understanding how myth operates is essential to understanding how fairy tales operate, as they are mythic tales. Rowland (1990) argues that myths and fairy tales are two very different things and that fairy tales do not have the same impact as myths because they are told strictly for entertainment. He derives this idea from Campbell (1991), but Campbell further explains that 
fairy tales are, in fact, a form of myth. He argues instead that fairy tales are myths for children and that different myths are important for different stages of life. Campbell (1991), much like Rowland (1990) does not view fairy tales as the true type of myth. That is, Campbell (1991) speaks of fairy tales as stories with fleeting importance in our lives. These two scholars do not take into consideration the lasting impact that these "childhood" myths can have on individuals. Rowland's (1990) argument that these stories are entertainment and therefore, useless as mythic tales blinds him to the impact that fairy tales have on individuals. Fairy tales are often the first myths that people encounter, and they allow individuals to be open to other myths and truly learn from them (i.e., the more sophisticated myths with which Rowland (1990) and Campbell (1991) are primarily concerned).

In addition to introducing the idea of myth, fairy tales also introduce the concept of archetypes. According to Jung (2014), archetypes are themes or roles that are a part of the collective unconscious. In other words, Jung believes that archetypes are ideas that we are predisposed to because of our participation in a collective society, so we both reproduce and reinforce them as a way of better understanding the world. An example of an archetype is The Mother. Jung (2014) argues that the idea of The Mother is so important to humanity, that we are able to recognize it from birth and as we grow, we identify this archetype repeatedly throughout experience, literature, and myth. Fairy tales are one of the first narratives that we are introduced to, which means that they also are our first introduction to these archetypes in story from. Though the stories may be intended for children, we form a connection to the characters as a personification of the archetypes for which we search.

These fairy tales that individuals are first introduced to as a child do not simply vanish after childhood. Instead, they're updated and re-imagined over and over, constantly a part of the 
popular culture. Familiar fairy tales are told repeatedly through different media, and they are widely successful. For example, many are familiar with the 18th century French tale Beauty and the Beast. This familiarity is probably not because so many individuals have read the original French tale but because of some interaction with one of the countless adaptations of the tale. The most notable adaptations in the past decade include a musical, ballet, several appearances in television (including an entire show), and four movies, including an incredibly successful liveaction version starring Emma Watson. I cannot agree with Rowland and Campbell that these tales have little lasting impact on an audience because they are entertaining. Instead, I contend that fairy tales should be examined as a type of myth, as they inform their audiences of social truths as well as have a lasting impact, especially on modern cultures.

If fairy tales are a type of myth, then it is important to first understand the framework of a myth and how a hero operates within a myth. Campbell (1973) is famous for introducing the idea of the monomyth. The monomyth is, simply put, a singular narrative or storyline that is present in all myths (Campbell, 1973). This omnipresent narrative that Campbell describes revolves around the mythic hero and his quest. The monomyth is easy to identify because there is a distinct separation from a known reality for the hero, initiation into a supernatural realm, and a return from the supernatural realm, during which the hero imparts all knowledge from the quest (Campbell, 1973). In addition to being known as the monomyth, many refer to this process as the hero's journey, and while this journey has been modified and condensed throughout the years, it still contains the separation-initiation-return that is essential to the monomyth (Vogler, 1985).

As Campbell and Rowland have strict definitions for what exactly a myth is, they also limit the definition of a mythic hero to that of a male. According to Campbell (1991), women do 
not usually have a substantial role in mythic tales. Women support the hero and aid in his journey, but they are not the hero. Campbell views women as the goal of the hero's journey, meaning that women do not need to fill the role of hero (Murdock, 1990). Not everyone agrees with Campbell's view of women's role in mythic stories. As a long-time therapist with countless female clients, Murdock (1990) had a hard time believing that women were content with just being the trophy for the hero. Instead, she saw the journey that women were on as unique and notable. Murdock (1990) directly challenged Campbell by creating an alternate framework for female heroes called the heroine's journey.

While there are many similarities between the heroine's journey and the monomyth, specifically the notion of separation, initiation, and return, there are a few differences that directly relate to my examination of OUAT. First, Murdock (1990) discusses the heroine's journey as more than just a journey for women (i.e., men can also be the hero in the heroine's journey). Murdock discusses the journey in terms of gender performance rather than male versus female. For example, the beginning of the heroine's journey is not just separation - as Campbell (1973) describes - but separation from the feminine. She sees the journey as first, an embodiment of hegemonic masculinity, and then, learning to embrace the feminine and integrating the two to become whole (Murdock, 1990). The second difference that I would like to highlight is that Murdock (1990) does not have a narrow definition for the "hero." Other scholars view the hero as an elite person that must contain specific characteristics and fulfill a specific function for society (Campbell, 1973; Campbell, 1991; Rowland, 1990). Murdock (1990) broadens the definition of "hero" to extend beyond that of a mythic hero and includes any individual that follows the heroine's journey in the definition. This alteration to the definition is 
significant because it allows individuals to become a hero through the transformation or rebirth they experience on the journey rather than already containing the essence of a hero.

While this broader definition of hero could potentially be problematic within mythic studies, I think it is the perfect lens for $O U A T$, as the series is a composite of countless different fairy tales and myths that all come together to create one larger story. This means that several characters could fulfill the requirements of "hero" beyond just the main characters. In addition to this, the series itself uses the term "hero" to describe anyone that is working toward defeating some sort of evil. Because of this loose definition of "hero" in the series, I think it is appropriate to use the same sort of language to both further discuss the nature of fairy tales and to examine OUAT.

Even with the broader understanding of women in myth and fairy tale, they still largely occupy one of two different roles in these stories: the hero or the villain. The most notable collection of fairy tales is that of the Grimm brothers, which OUAT and Disney use as inspiration for many of their tales. In Grimms' stories, the female heroes share many traits with their male counterparts, but the way these traits are portrayed is very different. For example, humility is a common characteristic of the heroes in these tales, but as the men seem to be born with this trait, the women must learn humility through the course of their story from particularly shameful experiences (Tatar, 2003). Along with humility, submission is a necessary trait for all female protagonists. This is different from their male counterparts, as male protagonists are often viewed as heroes, saving the day through their leadership and action; women, on the other hand, solve problems passively and can make the most impact when they are working within societal expectation (Tatar, 2003). A lot of these differences can be attributed to the patriarchal societies that created these different tales. Women are not often treated as being equal to men in the real 
world, so it makes sense that they must work harder to be seen as a hero by those around them (Murdock, 1990). Female characters do not usually have the same power to be heroes that male characters do because most iterations of women with power in fairy tales portray powerful women as villains.

Female villains are also portrayed very differently from the male villains in most fairy tales. In the Grimm tales, the most heinous female villains are the ones that do not possess an ounce of maternal instinct and have a substantial amount of power (Tatar, 2003). These tales often define what a good mother is and then put the female villains in direct contrast with that definition. For example, villains are often shown as step-mothers or mothers-in-law, highlighting the fact that they will never be able to fully fill their maternal role (Tatar, 2003). This portrayal of women in fairy tales has not changed very much over time. Even in the most popular recreations of these tales, women still must retain their humility and submission to be considered a good person, and women that have few maternal instincts are still vilified (Stone, 1975). This is important because most of the time female villains are women that also possess some sort of power outside of the home. They can do something that could have an impact on society. By portraying them as evil, these stories help to reinforce the traditional gender ideology that women are most valued when they are caring for others, and when they are not, they are considered wicked or corrupted in some way.

It is important to examine gender in fairy tales because fairy tales shape children's understanding of the world from a young age. They provide structure, outline the most important morals and beliefs in society, and can even empower individuals to act or stand up for themselves (Dewan, 2016; Ward, 2002). In other words, fairy tales provide a script for what is right and wrong and incite actions based on these judgments. This makes sense when 
understanding fairy tales as a subset of myth. The issue arises when the societal truths that fairy tales share are outdated or antiquated because the actions encouraged can be detrimental to the introduction of new thoughts and ideas. For example, if $O U A T$ is perpetuating a patriarchal ideology or glossing over the subtleties of sex and gender, the show is doing little to challenge the sexism in society and instead actually strengthens the notion that women should not wield power.

\section{Gender and Disney}

As the largest distributor of modern fairy tale and the parent company of $O U A T$, it is essential to understand Disney's recreation of the hero/villain dynamic and how gender factors into the story. Disney has created an entire empire on its retelling of popular fairy tales. In doing so, the company has essentially decided what values and morals should be important in our society, including what gender should look like (Brockus, 2004; Lacroix, 2004; Ward, 2002).

The sheer impact of Disney tales has spurred countless research on the subject, including several book collections just looking at the company's animated films (Bell, Haas, \& Sells, 1995; Cheu, 2013; Lacroix, 2004; Ward, 2002).

As $O U A T$ is a creation of Disney and directly pulls from Disney's most popular tales, we must examine what the typical story is for a Disney hero or villain in order to fully understand how these ideas and archetypes operate in the television show. There is a significant difference in what a male hero and a female hero looks like in Disney tales. One of the main differences between male heroes and female heroes is that male heroes are far more active than their female counterparts, but female heroes are more sympathetic than their male counterparts (Hoerrner, 1996; Kuykendal \& Sturm, 2007). In other words, female heroes (often princesses) are passive and demure compared to the male heroes. This difference in action can easily be attributed to a 
reflection of the patriarchal values that are embedded in society in the real world (Henke, Umble, \& Smith, 1996; Hoerrner, 1996). Women are supposed to represent all that is good and pure in the world; fighting does not typically fall into that definition but sympathy and compassion absolutely do. Even though female heroes wield much of the power in Disney tales, they are expected to do so with discretion (Rozario, 2004). This follows the pattern of maternity and submission that is expected of female heroes in fairy tales.

Heroes also represent the ideal, including the ideal version of their gender. Male heroes in Disney tales tend to exemplify the masculine ideal in society, including broad shoulders, rippling muscles, and a seemingly heterosexual lifestyle (Putnam, 2013; Sattar, 2016). This masculine ideal can easily be seen, for example, in Hercules. Although the hero begins as a scrawny teenager, he grows into a strong, muscled hero that women literally swoon over. Female heroes tend to typify the societal expectation for the ideal woman. Between the balletlike movements and the delicate animation, female heroes are seen prancing around while doing tasks often associated with the female gender, like housework (Bell, 1995; Henke, Umble, \& Smith, 1996; Sattar, 2016). It would be easy to assume that this representation of women is only present in Disney's early depictions of female heroes because these representations would have accurately reflected the value and expectations of women in the first half of the 20th century. This assumption would be mistaken, however, as even though some surface-level changes are made to make the female hero more modern, the underlying feminine ideal depicted in the early films is still largely present today (Henke, Umble \& Smith, 1996; Lacroix, 2004; Sattar, 2016). This is significant because several recent Disney productions - OUAT included - have attempted to lift women out of the submissive and passive roles from the past, but if these heroes are still being portrayed as the original feminine ideal, however veiled, the company is failing in its 
attempts and continues to send a message to its audience of what is expected of women. The Disney hero is a distinct and easily identifiable character, whether male or female, as the hero seems to fulfill all of society's expectations flawlessly.

Disney villains are just as iconic as their "good" counterparts. Just like Disney heroes, male and female villains differ throughout the different tales. One similarity between the villains in Disney films is that regardless of gender, villains seem to embody many traits of the opposite gender. In other words, male villains are feminized whereas female villains are masculinized (Putnam, 2013: Sattar, 2016). This is a stark contrast to the heroes of Disney tales, who epitomize what it means to be male or female. This is significant because a connection forms between villains' lack in character and their subpar gender performance (Putnam, 2013; Sattar, 2016). In addition to being more gender fluid, female villains have the added element of being far more sexual than their hero counterparts. This sexuality is typically viewed with disgust as female villains are portrayed as ugly, old, and undesirable (Bell, 1995; Carretero-González \& Rodriguez-Martin, 2009; Sattar, 2016). For example, Ursula from The Little Mermaid is an overweight, tentacle-clad sea witch that is certainly not as attractive as the thin, young mermaid, Ariel. Ursula is far more sexual in her actions, however, and some scholars have even discussed her appearance as akin to a drag queen (Sattar, 2016). It makes sense that Disney portrays sexual freedom as a negative quality because the company places such an importance on purity and innocence.

Most of the research on Disney films has been examining the animated films, with liveaction adaptations of the historical tales being a more recent phenomenon. While there is some research indicating that children are impacted similarly by animated media and live-action media, there is little research on how adults are impacted by the two (Kirsh, 2006; Tsay-Vogel \& 
Schwartz, 2013). OUAT is a live-action television show that incorporates many different fairy tales, including those that individuals have previously seen as cartoons. OUAT provides a very realistic form for stories and characters that have typically only been previously seen through animation, which has the potential to change the impact of gender performance on viewers.

\section{Gender in Popular Television}

In addition to the famous Disney tales, trends in popular media have also had a profound impact on how OUAT portrays gender throughout the show. While many television series attempt to empower women, it can be a difficult feat. As is often true in society today, sexism is heavily veiled in television shows. This is likely a product of the postfeminist world where feminism and its original goals seem outdated (Munford \& Waters, 2014). The first and second wave feminist movements have made explicit sexism - sexual harassment, sexist comments, and outright discrimination against women - unacceptable in society. This means that sexism now operates implicitly, something that is easy to overlook as a misunderstanding or not actually there. It is only when we identify patterns of behavior that the sexism truly becomes apparent (Bearman, Korobov, \& Thorne, 2009). Media tend to mirror the values of society, so it makes sense that the implicit sexism in society is also often present in the media (van Zoonen, 1994). I am very interested to see if this is also the case with OUAT. The series is taking on many tales that are rooted in sexist portrayals of their characters, so any alteration to those tales may seem like a huge improvement in the portrayal of gender. I am curious to see if gender is being represented differently throughout the story lines or if gender inequality is simply harder to spot because it is being put in a modern context.

Women on television, much like women in the real world, struggle with normative gender roles (Morgan, 2007). While they try to become more independent, they must be mindful 
of not becoming too independent as to threaten the hegemonic patriarchal ideology. This leads to characters like Jill Taylor from Home Improvement who seem to be more independent on the surface but actually continue to reinforce hegemonic gender norms (Dellinger-Pate $\&$ Aden, 1999). Although the series was celebrated as a welcome change to the depictions of women in the early 1990s, the authors argue that even in a seemingly equal relationship, masculinity is privileged over femininity. For Home Improvement and other similar series, success with a female audience is reliant on the fact that this inequality is heavily veiled. Only when the discourse between the characters is fully examined does the inherent sexism become apparent. Home Improvement is not the only show that attempts to include stronger female characters and story lines only to do the opposite. Even shows that follow lesbian characters struggle to include feminist notions throughout (Moritz, 2004). These characters are marginalized both as women and as lesbians, but they are rarely portrayed as advocating for their own rights. Instead, the lesbian characters are complacent and content - not a threat to the hegemonic patriarchal ideology (Mortiz, 2004).

There are countless examples of how gender is portrayed throughout television. Law and Order: Special Victims Unit $(S V U)$ is a notable example because the show is primarily centered on violence against women (Cuklanz \& Moorti, 2006). As I mentioned in the previous chapter, at the time of $S V U$ 's inception, violence against women, such as rape and abuse, was not widely discussed, especially on primetime television. $S V U$, one of the longest running crime dramas on television, uses the opportunity to cultivate new dialogue about gendered violence (Cuklanz \& Moorti, 2006). While the show and its actors work hard to shed a light on rape culture and gender violence, there are still glaring issues with the portrayal of female villains. Female villains in $S V U$ tend to be selfish and not maternal, reinforcing the negative female traits found in 
fairy tales (Cuklanz \& Moorti, 2006). If a contemporary crime drama series still pulls from older tales in their characterization of gender, is it possible for $O U A T$, which pulls directly from these older tales for their stories, to transcend these problematic portrayals?

Women are not the only ones stuck in a stereotypical position in television. Television continues to promote hegemonic masculinity throughout programming and advertisements, even through attempts at change (Feasey, 2008; Henson \& Parameswaran, 2008). A shining example of this promotion of hegemonic masculinity is the promotional materials for Old Spice. Old Spice commercials are famous for their hyper-masculine mascot that encourages men to become more like him (Kluch, 2015). Most masculine images on television are not quite as transparent as these ads, however. Reality makeover shows, like What Not to Wear, offer another interesting insight into the portrayal of masculinity in modern television. While these shows encourage men to engage in traditionally feminine behaviors like grooming and styling themselves, they do so only to encourage the hegemonic ideal of masculinity - that is, men are expected to conform to society's idea of what they should be (Weber, 2006). Both men and women are bombarded with hegemonic representations of gender in television, so when a television show like $O U A T$ alters the typical gender script, it is important to examine what is truly happening.

\section{Once Upon a Time}

OUAT provides apt opportunities to study the portrayal of gender in its blending of traditional/stereotypical fairy tale settings and tales and its morphing into contemporary, realworld settings. The television show has briefly been studied but not in the same way that I intend to examine the series. In the few studies found on $O U A T$, the research was focused primarily on the fantasy or magical aspect of the series. For example, Schwabe (2014) examined the magical realism in both $O U A T$ and another show about fairy tales, Grimm. She looked at 
how the different shows portrayed magic as either an embedded part of the real world or as a separate world that has some crossover into the real world. Other studies examined how $O U A T$ uses fairy tales to connect with the audience and create a bond that fosters audience loyalty (Hay \& Baxter, 2014; Wells-Lassagne, 2015). None of these studies examined how OUAT takes traditional stories and values and transports them into a modern realm or the effect of doing so. The few studies on the series do highlight its importance in our culture as both reinforcing common narratives that have remained significant throughout time and by continuing these narratives in a modern light. I propose examining this popular television series through a new lens to examine how certain values, specifically gender roles, have evolved from their traditional narratives into a modern setting. This allows us to be reflexive and observe if we are truly changing the messages behind the historic tales we are still fascinated with today. In the following chapters, I will address how gender is actually being communicated today through modern media messages that target our connection with these childhood tales, as these messages seem to convey a more contemporary understanding of gender.

RQ: Does $O U A T$ change the gender and power dynamics of a traditional fairy tale or does it reinforce the hegemonic patriarchal ideologies found in traditional fairy tales? 


\section{CHAPTER III: METHOD}

\section{Narrative Paradigm}

In order to analyze $O U A T$, I applied a critical narrative lens to the show. While this may seem self-explanatory when analyzing a series based on fairy tales, Fisher's $(1984 ; 1985)$

narrative paradigm argues that narratives do more than simply tell a story; they act as persuasive arguments for morals and societal truths. Rather than relying on reason and logic to understand reality, people are more likely to understand reality based on the stories they are told, especially if these stories resonate with their experiences. This concept is easily applied to OUAT, as the same Disney tales have long been teaching moral lessons to children (Ward, 2002). The impact of narrative should not be overlooked. Narratives can construct, reinforce, or deconstruct social realities, and Fisher (1984) notes that the most persuasive narratives are myths. This parrots what Campbell $(1973 ; 1991)$ and Rowland (1990) claim is the function of myth.

As narratives are such important tools to understanding the moral undercurrent in society, it makes sense to use this paradigm to explore media representations of gender. In this case, characters act as symbols or commonly understood pieces of the narrative that help to give the narrative meaning (Fisher, 1984). The characters in OUAT clearly symbolize moral truths regarding gender, as the characters themselves are often labeled "good" or "evil" throughout the series. This allows the audience to clearly discern which representations of masculine and feminine are celebrated and which are denigrated in society. Through this idea of symbolization, I will be examining characters in $O U A T$ as agents of morality and exploring the gender and power dynamics unique to each character. In examining the characters as such, I will be able to discern the true message OUAT is sending to its audience about gender and if it has, in fact, evolved from Disney's earlier depictions of gender in its earlier films and TV shows. 


\section{Once Upon a Time}

OUAT is a television show about traditional fairy tale characters, but their stories are told in a completely new context. These characters have been transported to Storybrooke, a small town in Maine in today's world, due to a spell cast by the Evil Queen, and they have forgotten (at least temporarily) who they are as they assume new names, identities and professions in their small town. The core narrative of the show is set in the present, but the viewer learns more about each character through flashbacks that introduce their fairy tale identities and help us understand their personality quirks and their motivations. Although the series alters the classic fairy tales, it makes a conscious effort to keep the fairy tale mentality, citing hope as the main theme throughout the series (ABC, n.d.).

The show recently finished its sixth season, and is very popular among a wide audience base. To illustrate its popularity, in October 2016, the show hit a series low of 3.4 million viewers (Mitovich, 2016). Even at its worst, OUAT reaches millions of people of all ages. Although its target demographic is young adults, OUAT is one of the few recent dramas on network television that has appealed to all family members, children included (Adalian, 2011). These statistics do not include viewers that stream $O U A T$ on Netflix or Hulu, as the series is available on both. Though Netflix is not often keen on releasing ratings or viewer information, they did disclose that in 2014 OUAT was one of two top streamed shows on the site (Pallotta, 2014; Siede, 2014). The wide range of audience members makes the discourse in OUAT even more important. This series plays on narratives that both children and adults are familiar with and largely focuses on the dichotomy of good versus evil.

In addition to the broad fan base, OUAT also has an extremely loyal and diverse fandom (Anne, 2013; Distasio, 2014; Romano, 2013). This means that not only is the series reaching a 
large audience, but it also means that this audience is tuning in week after week and is invested in the outcome of the characters. This dedication can easily be seen throughout the fandom. For example, fans have written over 76 thousand fan fiction stories (i.e., narratives that fans create for specific characters that are not a part of the broadcasted story). In addition to this, fans have created countless works of art of the characters. Lana Parrilla, the actress who plays Regina Mils/The Evil Queen, even changed her twitter avatar to a drawing of her character from a fan (Parrilla, 2016). This is just the tip of the iceberg for OUAT fans. Because of the large, broad, and loyal audience, $O U A T$ demands further inquiry into the messages that it is sending to this audience.

\section{Characters}

Instead of analyzing particular episodes of $O U A T$, as might be expected with such a project, I examined particular characters. I chose this method of examination over examining broader narratives for a few reasons. Most importantly, in fairy tales it is nearly impossible to separate the characters from the narrative, a point that is emphasized by Burke's (1969) description of the pentad. The pentad is connected to the idea that our entire world is a stage play, and there are five primary elements that create the pentad: the agents, the scene, the act, the purpose, and the agency. The characters, or agents, are connected to everything else in the narrative. They are impacted by and impact the world around them or the scene, as Burke calls it. This relationship and interaction that occurs between the scene and agents acts as a reminder to take into account the vast difference between how characters are represented in the "real world" vs. FTL (Burke, 1969). Gender is not something static that is easily seen in a few episodes; rather, gender is fluid and is constantly changing and evolving. To truly understand how gender is represented in this series, it is essential to track these changes within each 
character over several seasons rather than looking at snapshots of gender representations at a singular point in time. Because of this, I analyzed different characters and their development to see how gender operates for each. After this analysis, I synthesized my findings to discuss the series as a whole and how gender is generally addressed throughout the series based on my analysis of the different characters.

I have chosen several characters at the forefront of the series that I believe will provide an excellent representation of the series as a whole. I have specifically chosen these characters because they create three distinct dyads, which I briefly discussed in Chapter 1. Each dyad consists of characters that are very similar in how they act, their motivations, and how much power they hold in society, and they each consist of one male and one female. The good vs. evil dichotomy is clearest in FTL but quickly becomes a fluid entity, much like gender. I am interested to see how each character negotiates their gender after being originally marked as good, evil, or neither and how this affects their access to power. I will provide a brief description of each character below, but more information on each character, important relationships, and their story arcs can be found in the Appendix.

\section{Emma Swan}

Emma Swan is arguably the central character of OUAT. Emma is the daughter of Snow White and Prince Charming, but was sent to this reality as a newborn to avoid being caught in the Evil Queen's curse, as such she is a bit of an outsider to the FTL community. Emma's life is the antithesis of a fairy tale. Growing up as an orphan, she is shuffled from foster home to foster home until she finally runs away at sixteen. She survives by stealing what she needs and ends up in jail and pregnant as a young adult. With the birth father out of the picture, Emma chooses to give her son up for adoption before finding a new path as a bounty hunter. Emma is a stark 
contrast to her mother's character. She has had none of the same privileges and certainly does not have a prince counterpart. If Mary Margaret/Snow White is the historic female in a fairy tale, Emma embodies the modern woman. Understanding how Emma's gender operates and evolves throughout the series is essential to understanding how the creators and writers of $O U A T$ characterize gender in a modern age.

\section{Henry Mills}

Henry is Emma's biological son that she gave up for adoption. He was adopted by Regina Mills, also known as the Evil Queen. Henry is the one at the beginning of the series that propels all of the action. He is responsible for Emma's journey to Storybrooke and encourages her to stay in order to break the curse. Henry is still a child at the beginning of the series, so the audience gets to follow his development into a young man. Examining Henry’s gender throughout the series allows us the unique opportunity to see which behaviors are encouraged and which behaviors are discouraged by others, showing us how masculinity is negotiated and valued in the series.

\section{Mary Margaret/Snow White}

As a very strong supporting character, it is important to examine Mary Margaret, also known as Snow White. Mary Margaret's story remains very similar to the classic tale of Snow White - constantly battling her evil stepmother to remain alive - but her story begins to take a different turn once she enters Storybrooke, the land in our reality. In this new world, Mary Margaret is not universally liked by those around her, and she must learn how to deal with new and complex issues, such as infidelity and child abandonment. She is eventually married to her true love, David/Prince Charming, and the two learn to navigate their new reality together. 


\section{David/Prince Charming}

David/Prince Charming is easily seen as Mary Margaret/Snow White's masculine counterpart, as is expected based on the historic tales. In the Fairy Tale Land (FTL), Prince Charming helps rescue Snow White from the Evil Queen and wins her heart over in the process. The two do not begin together in Storybrooke, however, and David encounters similar challenges with infidelity in the beginning. Also similar to Mary Margaret, David's Storybrooke persona does not deviate too much from his Prince Charming persona. The two represent the historic fairy tales the most closely in the series, so analyzing their gender is extremely important in understanding how or if OUAT has evolved from the historic tales in their portrayal.

\section{Regina Mills/The Evil Queen}

Regina Mills/The Evil Queen is the creator of the curse that brought everyone from FTL to Storybrooke, Maine. Her story differs dramatically from the original tale of Snow White where she attempts to kill Snow White simply because of her beauty. Instead, the Evil Queen harbors a deep hatred of Snow White because of the girl's actions that led to the death of the Evil Queen's true love. Regina is an interesting character to examine because she often deals with the moral dichotomy of good vs. evil. She has also been in positions of power and of submission. In addition to this, Regina has adopted Henry as a single mother, putting her in a position of maternity, though some criticize her as not being maternal enough, as she juggles a career and her past. Seeing how Regina's gender is portrayed throughout the series can help us understand how power and morality are affected by and affect gender.

\section{Mr. Gold/Rumplestiltskin}

Finally, I will examine the character of Mr. Gold, also known as Rumplestiltskin. Much like Regina, Gold oscillates between positions of power and positions without. Gold also deals 
with the good versus evil tension, though he typically lands on the evil side of the equation.

Rumplestiltskin is first pictured as a submissive coward, but then he emerges as one of the most powerful beings in FTL - the Dark One. With some of the most powerful dark magic, suddenly Rumplestiltskin has power over others to use in any way he pleases. Gold/Rumplestiltskin is an essential character to examine because he is often seen as the most constant villain throughout the series. Examining how his gender has been portrayed throughout the series allows us to pick apart which aspects of gender are seen as good and productive and which aspects are characterized as evil or unproductive.

\section{Analysis Process}

As I analyzed several characters and the overall societies in the show, it is important to understand exactly what I looked at to form conclusions regarding gender. The unit of analysis for my study was two story arcs per character. These arcs were not limited to a particular season, as different characters experience growth and change at different times throughout the series. A story arc is different than an episode because it typically spans several episodes and brings a particular character into the forefront of the series to deal with a compelling problem. My criteria for a story arc was a specific storyline for the character of focus that includes a beginning, middle, and end. For example, I would not look at episodes where the character of focus was in a supporting role or not the focus of the storyline. I considered an arc finished when the major tension was largely resolved in some way. For example, in one of Emma's story arcs, she becomes the Dark One; the end of her reign as the Dark One also marks the end of this arc.

Examining two arcs per character will allowed me to fully explore how each character negotiates gender over time throughout the series. The two arcs I examined for Emma are when 
she is first struggling to control her magical abilities and fears becoming evil and when she is the Dark One (i.e., the embodiment of evil magic). The two arcs I examined for Henry are when we learn of his role as the truest believer as well as the arc where he becomes the author and uses these abilities. The first arc that I examined for Mary Margaret/Snow White is our introduction to her story as both personas, and the second arc will be when she fears she is becoming dark or evil after the death of Regina/The Evil Queen's mother. The first arc I examined for David/Prince Charming was also be his introduction story and how he came to be Prince Charming; the second arc was when he faces his greatest fear of being a bad father. The two arcs I examined for Regina/The Evil Queen were our introduction to her past and rise to power as both the Evil Queen and Mayor Mills as well as the arc where she separates her "evil" self from her "good" self. The two arcs I examined for Mr. Gold/Rumplestiltskin were his rise to power as the Dark One and when is forced to become a hero. I have chosen these arcs because they showcase each character as both good and evil, hero and villain.

When analyzing these arcs, I looked at things such as costuming, communication with other characters, rise/fall from power, parental instincts, and motivation behind actions, among other things. I also examined how each character interacts with their dyad counterpart to more fully see how gender is reinforced and how power is negotiated by similar characters of the opposite sex. I compared the gendered representations from FTL and the representations in Storybrooke for each character, as the two personas are represented very differently. After I examined each character, I synthesized my results for a better understanding of gender in $O U A T$ as a whole and the messages the show is sending to its audience. In the chapter to follow, I analyzed the six characters and synthesize my findings. 


\section{CHAPTER IV: ANALYSIS}

Throughout my examination of the different characters of $O U A T$, I found three distinct patterns in how the show portrays gender. First, the characters perform gender through their appearance. Second, they also perform gender through their character traits and actions. The show codes a specific type of gender performance as good, and anything short of that is coded as potentially evil. This is true for both male and female characters. Last, power and control almost exclusively lie with the male characters. Women are given very little access to power, and when they try to seek out more, they are considered evil and dangerous. As I continue to explain these themes, I will first briefly describe each character arc that I examined. Then, I will synthesize the information and discuss the larger themes and findings of this study.

\section{Characters}

\section{Emma Swan}

The first arc that I examined for Emma's character is when she was afraid of losing control of her magic and hurting someone. At the beginning of the episode, Emma has fully embraced her role as the Savior, but she is just learning how to call upon her magical gifts (Kitsis, Horowitz, \& Gierhart, 2014). Even though she is still learning to master her magic, Emma is able to use it to solve some problems with little effort. The trouble does not start until Emma is confronted with the image of her mother bonding with her baby brother - an experience that she never had, growing up as an orphan. Emma is unable to hide her jealousy of this experience in front of her mother, who admits to being nervous because this is the first time she has raised a child. "You've never raised a baby before. You just put one through a magical wardrobe," Emma says, referring to her own experience of being abandoned by her parents to an unknown realm so she would be protected from the Evil Queen's curse. During this interaction, 
Emma is holding one of her brother's bottles, which begins boiling due to magic caused by her jealousy.

This is just the beginning of Emma losing control of her magic. As Emma interrogates the Snow Queen for stealing her memories, the Snow Queen advises, "Don't let your emotions cloud your judgment," emphasizing that feeling emotions too deeply can be very problematic. The Snow Queen continues to push at Emma's buttons, causing her to lose any control over her emotions that may have remained. As Emma explodes, so does her magic, leaving a gaping hole in the wall of the sheriff's station and allowing the Snow Queen to escape. Emma's out-ofcontrol magic accidentally hurts her son, giving him a cut on his head (Goodman, Schwartz, Egilsson, \& Hemecker, 2014). She then decides to visit Rumplestiltskin to ask for help. She is so desperate for his help that Emma agrees to a deal without knowing the terms of the agreement - an action that could be very costly when dealing with the notoriously sly Rumplestiltskin. The only way he is able to help her is if she decides to give up her magic permanently. Emma immediately agrees to this option so she can keep Henry and the rest of her loved ones safe. Emma is stopped by her friend, Elsa, who explains why Emma's magic is going crazy in the first place and how it is linked to her emotions. Instead of allowing Emma to cut away part of herself, Elsa advises Emma to engage in self-care. "You have to love yourself, Emma. The good and the bad," says Elsa. Emma struggles with the decision to give up her magic or not. Ultimately, Emma accepts Elsa's offer for help and gains control over her magic once more by accepting the fact that she is capable of dangerous things, such as hurting the ones she loves, but she can learn to avoid such an outcome by allowing herself time to calm down and gain control over her emotions. 
The second arc that I examined for Emma was when she becomes the Dark One, the epitome of all evil magic. This arc starts by highlighting Emma's role as the Savior (Kitsis, Horowitz, Tirone, \& Hemecker, 2015). The dark magic that once resided in the Dark One escaped its cage and began searching for a new host, determined on taking over Regina. Emma, intent on saving everyone, takes in the darkness to save Regina. The darkness in its physical form looks like a black slime surrounding and crawling over Emma's body. Emma is transported from Storybrooke to a new world and rises from a pool of black slime (Kitsis, Horowitz, \& Underwood, 2015). Emma learns that it is much harder resisting her new dark urges than she thought it would be, especially since her dark thoughts are materialized in the form of Rumplestiltskin, a representation of all past Dark Ones. On her journey to finding Merlin, a sorcerer who can help rid her of the darkness, Emma accidentally chokes a man using magic. When Emma attempts to resist her dark impulses, her entire body shakes like she is in pain, and it is easy to see how difficult the task is for her.

Emma and her family continue to search for Merlin, calling on the help of King Arthur and his court in Camelot. While in Camelot, Emma still has visions of Rumplestiltskin, appearing delusional to her family and friends. They try to support Emma and trust her, but her family and friends begin to slowly pull away from Emma in caution. For example, Henry tries talking to Emma and helps her find a peaceful spot away from the others, but he does not confide in her about his new crush like he usually would. Hook continues to believe in Emma and denounces the Dark One as if they are not the same being. Emma does her best not to use her dark powers, but she has the most powerful magic of everyone and when one of her friends is in mortal danger, she uses her magic to save his life (Chambliss, Horgan, \& Tirone, 2015). Emma rationalizes that it is acceptable to use her dark powers as long as it is for good. Even so, 
Emma's appearance slowly begins to change the more she uses her dark powers, and eventually, she fully transforms into the Dark One.

Although the distinction between Dark Emma and the past Emma seems to come easily to everyone else, Emma does not feel as though she has changed drastically. She explains to Regina, "You of all people should know that there are no good or bad versions of ourselves. It's just me." This explanation does not sit well with those around her, however, who begin fully pull away from Emma, treating her as an outcast (Goodman, Schwartz, \& Egilsson, 2015). Emma attempts to reach out to Hook, who had proclaimed his love for her in Camelot would not change, but Hook no longer sees Emma as herself (Espenson \& Hemecker, 2015). She tells Hook that she's the same as her past self, just less scared about the future because now she has the power to protect those she loves. Hook disagrees and does not fall for the façade, intent on getting the "real" Emma back (Goodman, Schwartz, \& Hemecker, 2015). Emma's path to full redemption is a difficult one. She learns Hook, who she turned into a second Dard One to save his life, has used his new powers to bring back all of the previous Dark Ones from the Underworld (Horgan, Chun, \& Tirone, 2015). If they do not return to the Underworld, Hook has chosen her entire family as their replacements. To avoid losing her family, Emma decides to sacrifice herself, which would pull all of the Dark Ones back to the Underworld with her. In a moment of compassion, Hook chooses to sacrifice himself instead and takes all the darkness in. Emma is forced to stab the man she loves with Excalibur to save her family (Kitsis, Horowitz, \& Horder-Payton, 2015). Once she does this, she is transformed back into her past self, finally free from the dark magic. 


\section{Henry Mills}

The first character arc I examined for Henry is his role as the "truest believer." Henry is eleven years old, and it is just a year after he has convinced Emma to break the curse on the town (Kitsis, Horowitz, \& Hemecker, 2013). Henry is kidnapped because he is believed to have the "heart of the truest believer" by Peter Pan, who needs the magic that accompanies this to save Neverland and retain his status as a young boy forever. At eleven, Henry looks very young and small. He is much shorter than most of the other characters, including the Lost Boys and Pan. Although Henry is diminutive in size, he is not afraid to stand up to those around him. He is even able to plant doubt in his kidnappers' minds about the intentions of their leader, giving him a small bit of leverage over them. This is not the only time Henry exerts power over a situation. When confronted with an older boy who is clearly afraid, he takes it upon himself to comfort the boy, patting his shoulder. He remains protective over the boy he considers an ally, saving his life multiple times before taking control of the situation so they can get away from Pan and the Lost Boys. Eventually, Henry learns that the boy he thought was his ally was actually Peter Pan. He demands to know why Pan kidnapped him and what he hopes to gain from it. Henry remains demanding even when the Lost Boys surround him, all with weapons drawn. He does not cower in fear once, even though he is utterly defenseless against Pan and his Lost Boys and could easily be killed.

Pan preys on Henry's need to be a hero throughout the arc, hoping that Henry will easily be swayed to his side (Espenson \& Zakrzewski, 2013). "Magic is dying, and you, Henry, need to save it..." Pan tells Henry one night around the fire. As the need for Henry's heart grows, Pan warns him against his family's counterarguments, telling Henry that all heroes get tested on their journey and that he has complete agency over the choice to save magic or not. In reality, Henry 
could easily be forced by Pan's magic and the Lost Boys into giving over his heart. Henry listens to Pan, however, willingly giving his heart to the cause (Goodman, Hull, \& Solomon, 2013). At eleven, Henry is too naïve to understand Pan's underlying agenda or what it truly means to give his heart over to the other boy - his death. His family ends up defeating Pan and saving his life, and once the ordeal is over, Henry is content to be treated as a child once more, allowing Regina to call him her "little prince" (Boylan, Thomsen, \& Goddard, 2013).

The second arc I examined for Henry was when he becomes the author and uses these abilities to try and rid the world of magic. These two events happen at different times, but they both force Henry into the hero role, even after he loses all hope. When Henry first becomes the author, he is about thirteen years old (Kitsis, Horowitz, Egilsson, \& Hembecker, 2015). At the beginning of this arc, Henry wakes to find everyone from Storybrooke gone. He is left alone in the town and must find a way to save his family from whatever may be endangering them. To do this, Henry borrows a car and drives to a neighboring town, despite his young age. He learns that the author, a person specifically chosen by Merlin to chronicle the lives of everyone in the different magical realms, has once again abused his power and rewritten everyone's stories so the villains are the heroes and the heroes are the villains. As Henry enters this fictional world on impulse, he has no idea what to do once he enters this world other than try to change the story from the inside. He eventually finds Regina and tries to convince her that he is her son, as she has no memory of their past life. She does not believe him and even threatens him with a knife to his neck, but Henry does not back down and does not seem to fear for his safety at all.

He disregards his safety later on as well when he picks a swordfight with Rumplestiltskin, a hero in this world who still has his magical powers, after Emma has already been knocked unconscious by him. Henry does so to try and protect Regina because he is so 
sure that Rumplestiltskin will be unable to hurt him due to his hero status. Unfortunately, Henry miscalculates the lengths Rumplestiltskin is willing to go to retain his life as a hero, and is almost killed. He is saved by Regina who is badly injured by Rumplestiltskin. Scared for his mother, Henry insists that a kiss from her true love should revert everything back to normal, but again, he is wrong. When all hope is seemingly lost, Henry feels a pull to Isaac's magic quill, and when he picks it up, it begins to glow, indicating that the power of the author has transferred to him. He uses this power to write the story back to normal and saves Regina, along with the rest of the town.

Henry does not completely forego his authorial abilities, though. At about fifteen years old, Henry does something he said he never would - he uses the quill to manipulate events. Henry is very disenchanted with all magic, certain that it is the cause for all of the bad things that keep happening (Goodman, Chambliss, \& Tirone, 2016). "I used to think there was light and dark magic, but it's all bad," Henry tells his girlfriend, Violet. He uses the magic quill to acquire a crystal that all Storybrooke's magic is tethered to, intent on taking it out of town and destroying it. Henry does all of this without consulting anyone, sure that he knows what is best for the entire town. He and Violet travel to New York to find a means of destroying the crystal, but upon arriving, the two struggle to find any helpful information. This causes Henry to become incensed, and he is seen gripping a table, white-knuckled, shaking, and when he speaks to Violet, there is an underlying growling in his tone. His aggression does not stop here, though. When Violet thinks she sees something that could help in a glass case in the library, Henry does not hesitate to smash the case to get the item. As soon as they get what they need to destroy all of the magic, Rumplestiltskin finds the pair. Henry becomes protective of Violet and informs 
Rumplestiltskin that he will not get the magic without a fight. Rumplestiltskin responds by using his magic to briefly put the two teens asleep and grab what he needs.

Henry finds an opportunity to destroy magic while Rumplestiltskin is distracted by his moms, and he takes it (Kitsis, Horowitz, \& White, 2016). It is not until after the fact that he learns that his extended family is stuck in another realm with absolutely no way to get back to Storybrooke now that all of the magic has been destroyed. This is the first time that Henry has fully felt the weight of the consequences for his actions. As he talks to Emma, he gets an idea that could bring back the magic and subsequently save his family. Henry tells everyone that if enough people believe in the possibility of magic and make the same wish into the fountain, that it would be possible to bring magic back to the "Land Without Magic." Everyone is a little bit skeptical of Henry's plan, but they support it anyway. Confidence back, Henry climbs atop a statue in the middle of a busy park and addresses the public to urge them to help:

"I once let my own belief waver, but I was wrong. We need magic. It can make the world a better place. I know it seems impossible. But think about it, at some point in your life, every one of you was once a believer, and at some point, you left that part of you behind. But you can go back to it. If you believe."

Henry capitalizes on both this childlike wonder and unshakable confidence to convince the large group of strangers to do exactly what he asks. His plan works, and his family members that were stuck in another realm are returned.

\section{Mary Margaret/Snow White}

The first arc I examined for Mary Margaret/Snow White is when the audience first learns of each persona. When we are introduced to Snow White and Mary Margaret in "Snow Falls," it seems that the two personas could not be more different (Tigelaar \& White, 2011). During this 
arc, the main difference that we see between Snow White and Mary Margaret is that Snow White tends to be much more stubborn and brazen than her Storybrooke counterpart. Mary Margaret is quick to give into peer pressure and does not really know how to stand up for herself. She possesses qualities that make her seem much more maternal than her FTL persona. For example, Mary Margaret is a volunteer at the local hospital and reads to a comatose Prince Charming or rather his Storybrooke persona, David. Eventually David wakes up but has no memory of his past, including his wife, but he and Mary Margaret soon become enamored with each other. They do their best to give each other space because of David's marriage, but Mary Margaret begins to schedule her day around moments when she can bump into him just to see him throughout the day.

Snow White, much like her Storybrooke persona, also gets lovesick over Charming, even though he is to be wed to another. As her thoughts of him are keeping her from finally achieving happiness, she seeks Rumplestiltskin to fix the problem (Kitsis, Horowitz, \& Hemecker, 2012). Rumplestiltskin agrees that love is messy. He agrees to help and gives her a potion that will allow her to completely forget about Charming. Snow is hesitant to use the potion and holds off on it until she has more time to think it over. Both Mary Margaret and Snow White end up making huge sacrifices for Prince Charming/David. Prince Charming contacts Snow White before she uses the potion and says if she truly loves him, he will call off the wedding because he loves her too. King George warns Snow, as she arrives at the castle, that if she does not lie to Charming and tell him that she does not love him, he will kill Charming in order to save the diplomatic relations that the marriage intent on creating. Snow White gives into the king's demands and tells Charming to marry the other woman, as she does not love him. 
Meanwhile, Mary Margaret explains that she still has feelings for him, and it breaks her heart to have to see and interact with him all the time, knowing that she cannot be with him. The two try harder to stay away from each other so David can work on his marriage to a woman he now remembers but still does not love. This does not work out, and the two end up having an affair, beginning with a passionate kiss in the middle of the street. The sacrifice that Mary Margaret makes for David is not her love or memory, like Snow White. Instead, Mary Margaret sacrifices her propriety by engaging in an illicit affair with David. As the affair becomes public, Mary Margaret faces harsh criticism from those she considered friends, harassment, and even assault as David's wife slaps her at her place of work. We do not see David dealing with any sort of public shame or punishment for the affair; Mary Margaret takes the brunt of the abuse.

The second arc I examined for Mary Margaret/Snow White was when she was most afraid of becoming dark after the death of Cora, Regina's mother. At this point in the series, the curse has broken, and Mary Margaret remembers her past as Snow White. For simplicity, I will discuss this character as simply Mary Margaret from this point forward. Mary Margaret learns that Cora is the one responsible for her mother's death (Espenson \& Hemecker, 2013). She is furious and clearly wants to avenge her mother's death. She explains this to her husband, but he tells Mary Margaret that Cora cannot and should not die at her hands. Mary Margaret is briefly quelled from her path of revenge, but this does not last long. Rumplestiltskin offers Mary Margaret a solution to getting rid of Cora for good in the form a candle. He explains that she needs to light the candle over Cora's heart (which is not currently inside of her body) and then find a way to get her heart back into her body. Mary Margaret achieves the first step of the plan relatively easily, finding Cora's heart inside Regina's vault. As Mary Margaret does not have the power to magically remove/return someone's heart, she must find another way to do this. 
She quickly devises a plan when Regina catches her with Cora's heart and demands to know what she is doing. Mary Margaret explains that she was going to bring it to Regina in an effort to give Regina one thing she has always wanted - her mother to fully love her.

After Cora dies, Mary Margaret is inconsolable. She stays confined to her bed and refuses to talk to anyone or take care of herself (Goldberg, Chambliss, \& Barrett, 2013). Henry asks about her, and Emma explains that she feels responsible for Cora's death. "But she's Snow White. She wouldn't hurt anybody," Henry replies, unable to fathom Mary Margaret committing any act of violence. While the others all work on solving the next big problem in town, Mary Margaret stays home. Still overwhelmed with guilt, the first time Mary Margaret leaves her apartment is to go directly to Regina to ask to be killed. "And put you out of your misery? I don't need to destroy you. You're doing it to yourself," Regina tells Mary Margaret. "And along the way, you'll bring down that perfect little family you fought so hard to reunite." Regina's words cause Mary Margaret to begin sobbing as she continues to beg for her death, but Regina refuses. After her encounter with Regina, Mary Margaret takes the next day to herself to shoot arrows in the woods where finds August Booth, also known as Pinocchio, fully wooden and living in a trailer outside of town (Hull, Vasquez, \& Hemecker, 2013). He explains that he did not remain selfless, brave, and true, as the Blue Fairy said he must to stay a real boy. Mary Margaret remains hopeful, but August does not believe her optimism. "That's easy for you to say," he tells Mary Margaret. "You never had to worry about forgiveness... redemption. You've never needed it." Much like Henry, August believes that Mary Margaret is not capable of being selfish or doing something for which she would need to be forgiven. This fuels Mary Margaret's guilt, and she devotes all her energy to helping redeem August, thinking that in some way it might mean a second chance for herself, though she is still not confident. 
After may trials and sacrifice, August is finally transformed into a real boy once more for being selfless and redeeming himself, and Mary Margaret gains a small bit of hope for her own situation. This propels her to tell David about her altercation with Regina and her darkening heart. David asks why she kept this information to herself instead of telling him the truth. Mary Margaret responds, “Because telling you makes things real, and I needed to believe it wasn't, that I could find a way to stop it. That redemption was possible." David comforts Mary Margaret and tells her that they will get through it together, which seems to be enough to lift her from the guilt that had consumed her for days.

\section{David Nolan/Prince Charming}

When David first wakes from his coma in Storybrooke, he does not remember anything. We learn that he is married to a woman named Kathryn and seems to be quite popular among the townspeople, but David feels as though who he is now does not match everyone's image of him (Chambliss, Goldberg, \& White, 2011). This is something he struggles with greatly because he is obligated to Kathryn through marriage, but he continues to fall deeper in love with Mary Margaret, who saved his life after he woke from his coma. At first, David decides to leave Kathryn and convince Mary Margaret to be with him. He then encounters something that jogs his memory and suddenly remembers his entire life with Kathryn. David meets with Mary Margaret, but he tells her that he has changed his mind and wants to try and make his marriage with Kathryn work now that he remembers why he loved her in the first place, leaving Mary Margaret heartbroken, especially as she had rebuffed several of David's advances until this point.

David's alter ego, Prince Charming, also struggles with finding a balance between following his heart and doing the honorable thing. In the flashbacks of Charming's past, we 
learn that Prince Charming is not a real prince at all. In fact, the real Prince James was

Charming's twin brother, sold to the king for protection shortly after his birth so the king could have an heir to his throne. When the real prince dies in battle, Rumplestiltskin makes a deal with Charming and asks that he takes his brother's place. Charming does not expect this to be a permanent situation but soon learns he is wrong. Midas is so pleased with Charming's performance in slaying the dragon that he offers his daughter's hand in marriage. Charming is forced to accept and play part in the charade for fear of his mother's life. Resigned to fulfil his new duty as prince, Charming does not expect to fall in love with princess-turned-thief, Snow White. Much like David, Charming is forced to choose between the woman he has promised to marry, a union that would mean financial security for the entire kingdom for years to come, or the woman with whom he believes he is truly in love. Charming indicates that he plans on following through with his marriage to Midas's daughter, even though he does not look forward to the union.

David feels a similar limitation to his choices in Storybrooke. Even though he ultimately made the decision to stay with Kathryn, he still makes time every day to "bump into" Mary Margaret at Granny's Diner because he still has feelings for her (Kitsis, Horowitz, \& Hemecker, 2012). David explains to Mary Margaret that he feels like he has two conflicting selves, one who loves Mary Margaret and one who remembers loving Kathryn. Mary Margaret tells him to stay with Kathryn and try to make it work, as that is what he chose to do previously. Although David/Charming feels powerless in his respective situations, there is a recurring theme of choice. Mary Margaret constantly tells David he needs to make a choice, even after the two begin their affair. She wants him to tell Kathryn the truth, but he does not want to tell her about the affair for fear of hurting her. Mary Margaret makes her opinion clear and tells David that honesty is 
the best option and that he needs to choose which path to take. King George continually discusses Charming's impending nuptials, afraid that he will choose to abandon the wedding. The king's fear implies that Charming does still have some semblance of power over the situation, even if it is a bit more limited than David's.

The second arc I examined for David/Charming is the closest he gets to becoming dark. David is forced to literally face his biggest fear in the form of a fight against himself (Hull \& Hemecker, 2014). The arc begins in the middle of a dream where Charming finds Emma in the old nursery they had for her but never got to use. The dream quickly turns into a nightmare when Emma gets sucked into the wardrobe that originally transported her to the "real world." Charming startles awake, drenched in sweat and panting from the nightmare. Snow finds him and asks him about it, but he brushes it off as nothing. She then confides in him that she is pregnant, immediately bringing all his fears to life. Charming takes a break from talking with Snow to go out to the stables and sneak a drink of alcohol. He runs into Robin Hood, who asks Charming about his day drinking. Charming confides in the other man. Robin then tells Charming of a root that can help someone overcome their fears, but warns him that it is very difficult and dangerous to get ahold of the root and cautions him against the journey. When confronted by Snow about his fear regarding the new baby, Charming denies everything, even after Snow admits that she is afraid of failing the new baby like they failed Emma.

Charming ingests the root that is supposed to help people overcome their fears without realizing it. The way this root works is that it manifests someone's greatest fear as another version of themselves that they must defeat. As Charming and the others are on the hunt for Zelena, a new threat in town, he does not realize that he is fighting himself when he first confronts the hooded figure in the woods. Charming, who is usually an excellent swordsman, 
cannot seem to get the upper hand when fighting the hooded figure but eventually gets in a position that allows him to unhood the person, revealing himself. The doppelganger begins to taunt Charming. "You can't defeat me," he says to Charming. "I can smell your fear. It's like a stench. The stench of a scared shepherd boy who strayed too far from his farm." Charming denies being afraid of anything, but the doppelganger breaks his sword, leaving him at a great disadvantage. It is not until Charming finally admits his fear of being a bad father to the new baby that he can defeat his doppelganger. After he does this, Charming decides to finally confide in Snow about his own fears. She tells him she is glad he shared this with her but not to worry because they can lean on each other throughout the process and help each other be the best parents to their new baby.

\section{Regina Mills/Evil Queen}

The first arc I chose to examine for Regina/Evil Queen is when her character is first fully introduced to the audience. This happens over the course of the entire first season, as we gradually learn about her past in FTL and her motivations in Storybrooke. Both the Evil Queen and Mayor Mills are not easily deterred from a plan once they make up their mind. The Evil Queen, for example, hunts Snow White for years to either kill her or make her lose her happiness (Kitsis, Horowitz, \& Barrett, 2011; Kitsis, Horowitz, \& Beeman, 2011; Kitsis, Horowitz, \& Mylod, 2011; Kitsis, Horowitz, \& White, 2012). She goes as far as enacting the "dark curse" that pulls everyone from FTL and brings them to a new reality where they have no memories of their previous lives and new circumstances keep them from the ones they love. To cast this curse, Regina must first fight and defeat one of her best friends, Maleficent, who currently has possession of it. Then, she goes to Rumplestiltskin to clarify exactly what she must do from there. He tells her that for the curse to work, she must kill the things she loves most - her father. 
Regina's desire to hurt Snow White is ultimately stronger than her love for her father, and she decides to cast the curse.

Regina's determination does not change once she enters Storybrooke. While Snow White has been stripped of her happy ending, Regina finds a new enemy in the form of Emma Swan. When Emma comes to town and threatens to demolish her already strained relationship with her son and her curse, Regina vows to force Emma out of town (Espenson \& Edwards, 2011; Espenson, Goodman, \& Cheylov, 2012; Espenson \& Waxman, 2012; Goldberg, Chambliss, \& Spicer, 2012). She tries many different things, including falsely arresting her for drunk driving, getting her evicted from the local bed and breakfast, and even publishing in the local newspaper the fact that Emma gave birth to Henry in prison, a fact he did not know. Unfortunately, all her efforts are futile as Emma moves in with Mary Margaret and becomes the town's new sheriff.

The second arc I examined for Regina is during the most recent season when she magically split from her evil half and became two different individuals. For clarity, I will discuss the original character as Regina and the split half as the Evil Queen. Before she splits herself, Regina describes her life as being full of pain and suffering due to her deeds as the Evil Queen (Kitsis, Horowitz, \& White, 2016). She clearly regrets these actions and is afraid that something will make her evil side come back. Her alter ego is something that haunts her even as she attempts to redeem herself. She cannot see herself as a good person no matter how often she acts as a hero because she cannot escape all of the harm she has caused. Snow White, who recently returned to our world with Dr. Jekyll, suggests that Regina take similar action as he and split herself into two parts - good and evil. Then, Regina could kill her evil self and be entirely good. Without knowing how it works exactly or the potential risks, she allows Snow to inject 
her with a serum that begins the process of splitting herself. This process looks incredibly painful. Regina is shaking and grabbing herself, trying to escape the pain. After a few moments, she comes face to face with the Evil Queen. Although killing the Evil Queen is exactly what she wants, Regina hesitates but then kills the Evil Queen in the same way she used to kill others, by ripping her heart out and crushing it. It seems as though this works, as the Evil Queen turns to dust before their eyes. When they get back to Storybrooke, Mr. Hyde warns Regina, "Despite what you may think, darkness is not as easy to snuff as you may believe."

We learn that Regina did not actually kill the Evil Queen, like everyone thought (Kitsis, Horowitz, \& Egilsson, 2016; Chambliss, Horgan, \& Underwood, 2016). The Evil Queen uses this to her advantage and keeps her presence in Storybrooke a secret for as long as possible. With the Evil Queen gone, Regina worries that she has also lost her strength. When Hyde continues to be a threat to the town, Regina warns Emma that she does not know if she has the strength to help fight him. Thankfully, she has many people in her corner to let her know that she is still strong without the Evil Queen. Having others cheer her on does not stop Regina from being selfdeprecating, though (Chambliss, Hales, \& Duncan, 2016; Horowitz, Kitsis, \& Buckley, 2016; Espenson \& Hemecker, 2016). Regina often speaks as though she was the most evil and heartless person in existence, but it could easily be argued that characters like Rumplestiltskin or Cora are much darker in actions and intentions than the Evil Queen ever was.

The Evil Queen traps Regina and Emma in a hidden world and impersonates Regina (Schwartz, Fong, \& Lynch, 2016). She takes over the role of Henry's primary caregiver under the false story that Emma went out of town to find more information on how to get rid of Hyde. Henry notices the difference right away. For instance, the Evil Queen is much more concerned about outward appearances than Regina. She tells him more than once that "posture is self- 
respect" and reminds him that he is a prince and should act like it to impress his girlfriend. The Evil Queen tries to get Henry to kill the Dragon, who has become a mortal threat to Emma and Regina, still trapped in the other world. Henry refuses again and again, but the Evil Queen tells him that she did not raise him to be weak. Henry ends up not killing the Dragon, and the two women find another way out of the other world. The Evil Queen separates the bond between herself and Regina, which is the only thing that kept either of them from killing the other (Chambliss, Horgan, \& Underwood, 2017; Goodman, Hales, \& Woods, 2017). A fight between the two begins, and Regina gains the upper hand and rips the Evil Queen's heart out, but she is unable to crush it as she had previously. Instead of killing the Evil Queen, Regina takes out her own heart as well. She transfers some of the Evil Queen's darkness into her heart and transfers some of her light into the Evil Queen's heart. She puts the heart back into the Evil Queen's chest. After weeks of trying to battle the Evil Queen and find a way to destroy her, Regina realizes that she should not be striving for destruction anymore. Instead, she uses her newfound love and appreciation for herself to help redeem the Evil Queen, though others doubt the outcome.

\section{Rumplestiltskin/Mr. Gold}

The first arc I analyzed for Rumplestiltskin is his introduction in both worlds and how he became the Dark One. We see Rumplestiltskin in FTL before he is the Dark One, and he is dirty and sweaty and walks with a limp (Espenson \& Waxman, 2012). His clothes are so worn that they barely resemble items of clothing any longer and look more like rags. Rumplestiltskin is horrified when he watches a young girl be taken from his village to fight in the ogre wars. He learns that the kingdom has lowered the age of the draft and that his son is set to be taken in three days on his birthday. Rumplestiltskin tells his son, Bae, that they will find a way out of the draft. 
By this, he means that he intends for them to run away. They make their way out of town but are soon caught by the guards who have been taking the children from town. They identify Rumplestiltskin as the man who ran from the war. Rumplestiltskin begs the man to leave Bae alone and asks what it will take. The leader of the pack, identified as the duke, tells Rumplestiltskin to kiss his boot, and Rumplestiltskin complies. The guard laugh at Rumplestiltskin's cowardice and kick him before they turn and leave. Although he is humiliated, Rumplestiltskin did achieve his goal of saving Bae from being taken for at least a little while.

Rumplestiltskin and Bae are forced to go back home, as the guards now know they were trying to escape the draft. Rumplestiltskin is at a loss for how to save his son from being taken to war. A beggar that Rumplestiltskin and Bae came across on their attempt to run offers to help and tells Rumplestiltskin that the Dark One, who has been protecting the guards with his magic, is being manipulated by them through a dagger. All Rumplestiltskin has to do is find the dagger, and he will be in control of the Dark One. Rumplestiltskin plans on burning down the castle of the duke, who holds the dagger, putting everyone inside in danger. He has his son help prepare torches and even brings him along when setting the castle on fire. After Rumplestiltskin acquires the dagger, he makes a point to send Bae home. At this point, he is planning on killing the Dark One in order to take his power. He does not want Bae to witness this act, however. Rumplestiltskin then summons the Dark One and stabs him with the dagger. It is not until the next morning that Rumplestiltskin returns home, transformed into the Dark One. When he arrives, he finds that the guard is there, ready to take Bae with them. Rumplestiltskin announces his new status as the Dark One. He makes the duke kiss his boot in retaliation for their previous encounter. The duke complies, but instead of kicking him like the others did to him, Rumplestiltskin breaks the man's neck. He then kills the other soldiers, all in front of his son. 
Bae admits to Rumplestiltskin that he is afraid. Rumplestiltskin responds, "I'm not. I protected what belongs to me. And I'm not scared of anything."

In Storybrooke, Rumplestiltskin is known as Mr. Gold. He is the landlord of many different businesses in town, in addition to owning his own pawn shop. Most everyone in Storybrooke distrusts Gold but sees him as a necessary evil at times. For example, Emma accepts Gold's help to win the race for sheriff over Regina's pick. She understands that doing this is dangerous, as Gold does not play fair, and Emma eventually regrets her decision after Gold sets fire to Town Hall to create a situation for Emma to be a hero. People in Storybrooke are afraid of Gold. When he pays Emma a visit to offer his services as her "benefactor" in the running for sheriff, Emma's roommate, Mary Margaret, literally runs from the room because she is so intimidated by his presence. This is a far cry from how people viewed Rumplestiltskin before he became the Dark One. He even tells Emma later, "Everyone's afraid of Regina, but they're more afraid of me." It seems that the townsfolk have a good reason to fear Gold, as he will go to any lengths to get what he wants. An example of this is when Moe French steals from Gold. Gold takes matters into his own hand and kidnaps and tortures the man to find his possessions. He ends up sending Moe to the hospital after beating him so badly, forcing Emma to arrest him for assault.

The second arc that I examined for Rumplestiltskin is after Emma takes all of the darkness and becomes the Dark One, leaving Rumplestiltskin a blank slate and the opportunity to become a hero. When Emma returns to Storybrooke as the Dark One, Rumplestiltskin is in a coma due to his heart, which is deteriorating quickly due to all of the darkness he took in as the Dark One (Kitsis, Horowitz, \& Tirone, 2015). Emma heals his heart and kidnaps him because she needs him to become a hero so he can remove Excalibur from the stone it is encased inside. 
Rumplestiltskin is forced to train against his will with Merida to learn how to be a hero. Merida begins by teaching him how to swordfight, something he does not know how to do very well. He wants to give up before even beginning the training. He feels absolutely hopeless without his powers. Merida knocks Rumplestiltskin unconscious for a few hours and ties him to a tree while she devises another plan to help him become a hero. He wakes up, and she lifts her sword up to cut him free, but he flinches like she is going to kill him right then. Merida finds the teacup that was also stolen in the first arc that prompted Gold to torture Moe. The teacup represents his love for Belle, who has left him because he would not give up his evil ways. Merida uses this token of affection to try and spur a reaction from Rumplestiltskin. As she continues to taunt Rumplestiltskin, he finally grabs his sword and goes after her. Merida is pleased with his progress and tells him that by thinking of Belle instead of himself and fighting with her in mind, he was finally acting bravely. After their encounter, Merida ties Rumplestiltskin up and goes to find Emma to share their progress.

Although Merida believes he is finally becoming brave, Rumplestiltskin does not believe her, and again, he tries to run. He takes the teacup that Merida stole and breaks the sentimental token so he can use the shards to cut himself free. He is able to get away before Merida and Emma get back to the camp in the woods. Emma then orders Merida to put an arrow through Belle's heart to force Rumplestiltskin into being a hero. Meanwhile, Rumplestiltskin finds his way to the library where he knows he will find Belle. The two talk, and he realizes that Emma will not be coming after him. She will be targeting Belle to force him to be a hero. Rumplestiltskin devises a plan, but Belle soon learns that Rumplestiltskin's plan to defeat Emma had actually been a plan to leave town (Chambliss, Chun, \& Hemecker, 2015). She does not realize this until Rumplestiltskin is nearly driving them over the town line, and she asks him to 
stop. When he refuses, she opens the car door while still moving to get out. Rumplestiltskin does not understand why she will not leave town with him.

Belle: "You know, running never made anyone a hero, okay?"

Rumplestiltskin: "Don't you get it? I'm not a hero."

Belle: "Well, you've been brave before."

Rumplestiltskin: "When? During the First Ogre's War? Let me tell you the truth about that day. I didn't... cripple myself to get back to my son. I did it because I was scared. I joined the army to prove I wasn't a coward. But when I seen [sic] the wounded coming back from the front lines, I didn't want to die. I'm a coward, Belle. And that's never going to change.”

Instead of responding to Rumplestiltskin's admission, she turns and walks back into town without him. She is stopped by Merida, who is forced to take a potion that changes her into a bear. Unable to reason with a bear, Belle attempts to run away but is soon cornered. Rumplestiltskin finds Belle being attacked and uses the magic he was going to use when leaving town on Merida, causing her to turn back into a human. Belle tells Rumplestiltskin she knew he had the bravery inside him to truly be a hero. As they have accomplished their goal, Merida leads the group back to Emma.

\section{Appearance}

The first main theme that I will discuss is how characters in $O U A T$ perform gender through appearance. Much like other television shows, OUAT codes gender first based on appearance. As the differences in appearance are more pronounced for female characters, I will discuss these first. For a female character, traditional femininity is considered good and pure and almost always rewarded in some way. Snow White is a shining example of this. In one of the 
first flashbacks we see of Snow White, she is on the run from the Evil Queen (Tigelaar \& White, 2011). She's been living in the forest of the kingdom, stealing and making deals in order to survive. For someone living in the forest, she is still remarkably clean and feminine. She wears a cloak with fur, gloves, and is outfitted in leather accessories. Both her shirt and pants are made of white material, and while her clothing shows a little wear, it is all still in very good condition. Much like her clothing, Snow White's famous black locks are present and flowing. While her hair is a bit unruly, it is still styled and maintained. Although Snow is sometimes seen with dirt smudges on her face, the most notable features are her rosy cheeks and bright pink lips. Mary Margaret is essentially the embodiment of femininity. She is almost always seen wearing a dress that is usually floral print and a cardigan of some kind, along with very delicate jewelry. She wears light makeup that again highlights her rosy cheeks and bright pink lips. The biggest difference between Mary Margaret and Snow White in appearance is that Snow's hair is long and wild, while Mary Margaret sports a pixie cut throughout the series.

Emma does not quite fit into this traditional femininity. Emma has long, blonde hair, often curled or styled in some way that looks effortless but is clearly not. She is wearing light but noticeable makeup, such as eyeliner, some sort of nude eyeshadow, and a light layer of lipstick. Emma is almost exclusively seen wearing jeans, along with one of her trademark leather jackets. Overall, Emma is presented as feminine but not "girly." By this, I mean that Emma does engage in feminine beauty routines, such as wearing makeup and styling her hair, but she does not typically embrace the styles most associated with feminine women, such as floral print or dresses. As Emma does not fit the appearance of traditional femininity, she is not coded as a solely good character. Emma is mostly good, as she is the Savior and daughter of Snow White and Prince Charming, but she does carry the potential for evil. This is a significant 
difference from Snow White's character. One explanation could be that Emma is not from FTL, and the lines between good and evil are not as clear in the "real" world. While the extreme cases of traditional femininity and oversexualized femininity still carry the same implications, it is rarer to find individuals who fit these types of appearances outside of FTL.

Oversexualized women, such as Regina, on the other hand, are considered dangerous and evil. A great example of this is the Evil Queen's attire in the pilot episode (Kitsis, Horowitz, \& Mylod, 2011). Regina is dressed in black from head to toe. Her long hair is tied in a ponytail and accompanied by an elaborate headpiece. Like most of the Evil Queen's attire, the bodice of her dress is a corset, revealing a scandalous amount of cleavage. The corset leads to a long, flowing black dress. The dress is covered by an overcoat with imposing shoulder pads and black and red feathers peppering the back. The Evil Queen is wearing much more makeup than anyone else in attendance of Snow White's wedding, with a bold smoky eye accompanied by bright red lips. Just from her appearance, it is obvious that Regina is not afraid to break society's norms, as she looks extremely different from every other woman in the room. Every other woman is wearing either natural-looking makeup or wears colors that are typically coded as feminine, such as white, blue, pink, etc. Mayor Regina Mills' appearance is a bit different than the Evil Queen's, but it does not stray terribly far. For most of the first season, Regina only wears black, grey, red, or purple clothes, like her Evil Queen persona. She steers clear of the pastels that Mary Margaret is frequently seen wearing. Mayor Mills has a short bob that is usually styled with a slight curl at the ends. She consistently wears heels, which can usually be heard clicking against the hardwood or tiled floors, signaling her imposing presence. She still wears darker makeup than those around her, usually in the form of eyeliner and a darker lipstick. 
A complete lack of femininity is also a sign of potential darkness in a female character. A great example of this is when we see Emma fully transform into the Dark One in (Chambliss, Horgan, \& Tirone, 2015). Instead of her usual light blonde hair, she now has white hair that is braided into a tight knot on the back of her head. She is wearing a long black trench coat over a short black dress with black pantyhose and black heeled boots. Her skin is paler and shiny, more akin to an animal skin than a human's. Even her tone of voice and posture changes, both becoming more harsh and stiff than her previous relaxed attitude would allow. In "Nimue," we learn of Nimue, the first Dark One (Espenson \& Tirone, 2015). She was styled similarly to Emma with her hair pulled tightly back, minimal makeup that did not highlight full lips or rosy cheeks, and a long black cloak hiding her figure.

The physical appearance of male characters is also important in understanding the difference between good and evil in OUAT. If Mary Margaret/Snow White is the model for traditional femininity, David Nolan/Prince Charming is the quintessential male character. His appearance fits what most would expect from a modernized version of Prince Charming: tall, slightly rugged appearance, and always a smile on his face. David wears flannel, jeans, and Carhartt-type jackets, all of which are typical of the men in Storybrooke, Maine. David's FTL persona, Prince James, also known as Prince Charming, tends to wear tighter clothes and leather much more than his Storybrooke counterpart. Both seem to embrace the standard men's fashion for their respective time and place. David is muscular, has a deep voice, and looks capable of winning a physical fight. These are all indications of a good male character. Although Henry is not yet grown, he is beginning to fit these descriptors, just like his grandfather. He is typically seen wearing jeans, some sort of flannel shirt or hoodie, a scarf, and a coat. His attire stays the same throughout the series, only changing to match his new height as he grows older and taller. 
The appearance guidelines for women are stricter than for men. Although there are particular types of clothing that are unacceptable for women (i.e., tight, sexual clothing or masculine clothing), the only appearance that is unacceptable for men is one that resembles a feminine appearance. As long as men are not feminine-looking, they are respected and seen as good until proven otherwise. Rumplestiltskin proves to be a good example of not living up to the masculine appearance guidelines. When we see Rumplestiltskin in FTL through flashbacks before he was the Dark One, he is dirty and sweaty and walks with a limp. His clothes are so worn that they barely resemble items of clothing any longer and look more like rags. His hair is long, unruly and unclean. The dirtiness of Rumplestiltskin is vastly different than Snow White when she is living in the woods to escape the Evil Queen. Snow White has little more than dirt smudged on her face and is still considered very beautiful and almost regal. She is still wearing nicer clothes, appropriate for the weather and conditions of the forest. Rumplestiltskin is dirty to the point where his skin looks darker in color. His clothes would barely provide protection from the elements if he were stuck in the woods, and he is clearly more poverty-stricken than Snow ever was, making him look more feeble and weak. Gold's appearance is vastly different than Rumplestiltskin's. He is always wearing a dark suit with some pop of color, even when working with messy chemicals. His hair is still long, but it appears much healthier and taken care of. Gold still walks with a limp, but his walking stick is now an ornate cane.

In general, Rumplestiltskin is not a masculine man. He has many feminine attributes, especially as he begins to transform into the Dark One. Rumplestiltskin is diminutive. He is short and not muscular in any sense of the word. He has long hair throughout most of the series. As he becomes the Dark One, his voice becomes more feminine, his nails look very similar to the style and length of acrylic nails that many women wear. His skin becomes scaly and slimy. 
His hair is still long, but it is wirier and more out of control than before. His voice also changes and becomes higher. His teeth are more yellow and full of grime than before. Overall, Rumplestiltskin looks rotten. I mean this in the sense that his body has become more green and yellow in color, and he looks much more grotesque than before, like a piece of fruit rotting over time. His attire also changes when he transforms into the Dark One. Rumplestiltskin now wears wild jackets over plain shirts and pants with different broaches and other ornate accessories. As the Dark One, he is described by many as impish, which refers to a creature that is childlike and creates mischief on the same level as a poltergeist. This does not suggest an imposing or commanding presence. As long as men are not feminine-looking, they are respected and seen as good until proven otherwise.

When Prince Charming, Snow White, the Evil Queen, and Rumplestiltskin share a screen, it is quite easy to pick out who is good and who is evil without knowing anything about their characters or the series. This is because their appearances are no different than what we might expect from a hero or a villain; they simply reinforce our notions of masculinity and femininity. This is powerful because it continually teaches its audience to value certain things, like modesty for women and physical strength for men. These appearances are not reflective of society, however, meaning that these lessons are then translated onto a reality in which they do not fit.

\section{Traits and Skills}

The second way OUAT performs gender is through coding certain traits and skills as masculine or feminine. Desirable feminine traits in OUAT include maternity and selflessness, just as past research would suggest (Tatar, 2003). If a woman does not possess these traits, she is considered more evil and dangerous. First, I will discuss maternal instincts and how they factor 
into coding a female character as good or evil. Snow White/Mary Margaret is probably the best example of a maternal character in both personas, although Mary Margaret tends to be the most maternal. For example, Mary Margaret is a volunteer at the local hospital and even gets her students involved in bringing joy to the patients. When Henry asks that she read to a comatose patient, she complies, even though she thinks it is silly. Mary Margaret sits on the patient's bed while reading, not unlike a parent reading to a child at bedtime. When Mary Margaret realizes that Emma is living out of her car after being forced out of the bed and breakfast, she immediately offers her extra room to the woman, worried about her sleeping in her car. Mary Margaret also takes a deep interest in Henry's well-being, willing to do seemingly ridiculous things to help him get over his fairytale obsession. Even as she is in jail and being investigated for a serious crime, Mary Margaret takes the time to make her bed in the cell, a very domestic act that would be unusual for any other character.

One of the most notable maternal moments for Mary Margaret occurs after Emma attempts to skip town without saying goodbye (Espenson, Goodman, \& Cheylov, 2012). "You said we were like family," Mary Margaret confronts Emma, clearly hurt by the other woman's actions. She reminds Emma that she has to do what is best for Henry now. Emma asks what that might be, but Mary Margaret is quick to remind Emma that she is the boy's mother and must figure it out on her own. It is obvious that Mary Margaret deeply values close relationships, especially those that she considers more familial. She is extremely hurt and shocked by Emma's actions and even makes Emma feel guilty for not acting maternal enough and considering Henry's needs. Snow White's maternal instincts begin to arise when she finds herself in the company of the dwarves. Snow is living with them, so she does her part in cleaning, cooking, 
and generally helping around the house. It seems that caring for others is just as easy for Snow White as it is for Mary Margaret.

Regina, the evil one, should not have any maternal instincts, but this is not necessarily the case. While Regina's love for her son is unquestionable, the way she demonstrates this love is. Maternal instincts are typically defined as the instinct that a woman must protect someone or something else from harm, usually a baby, but what this looks like in practice is much more difficult to define. Regina clearly cares about protecting Henry from both physical and emotional harm, but the way she communicates this is not what you would expect from a mother. Regina is strict and does not explain her intentions beyond the fact that her actions are to protect Henry. She does not coddle Henry and can be read as a very cold and uncaring mother. For example, Henry sneaks out of his house to meet up with Emma and Mary Margaret. When Regina finds him, she tells him that they will discuss his "insubordination." She asks if he knows what this means, and he says no. She responds that it means he is grounded. Rather than explaining how worried she was for his safety and why it is important that he heed her instructions, Regina simply doles out a punishment and lets Henry know he was in the wrong. Another example of this practical mothering is when Regina decides to demolish a wooden castle jungle gym that Henry loves to frequent without her supervision. Henry is devastated by the act, and Emma is livid that Regina destroyed something that Henry loved so much. Regina explains to Emma that the jungle gym was extremely old and dangerous and that she was simply protecting Henry from getting hurt. I find it interesting that in this moment, Emma seems to be the more maternal figure for Henry because she acts based on her emotions. Regina, who tends to suppress all emotions to be more logical, seems less maternal, but she is more concerned with protecting Henry from harm - the very thing that makes someone maternal. 
But, because Regina keeps her feelings to herself, she is considered not maternal and seen as more dangerous. Regina is also a great example of how women are not expected to be taskoriented. If Regina were a male character instead of a female character, her actions would be lauded as great parenting because men are not expected to be quite as nurturing or emotional. They can focus on accomplishing tasks instead of cultivating relationships, but as Regina is a prime example, women are expected to focus all of their energy on their relationships with others.

Of course, when analyzing Regina's motherly instincts, it is important to briefly discuss her role as Snow White's step-mother and her subsequent vendetta against Snow White. I do not believe it is fair to examine this relationship as a mother-child relationship for a few different reasons. First, Regina is closer in age to Snow White than the king, putting them on more of a peer to peer level. Before she marries the king, Regina also acts as more of a friend to Snow than a motherly figure. From what we see of her relationship with the younger Snow and the king, Regina has very little say in anything. She does not have the opportunity to nurture or care for Snow as the king devotes all his time to doing so. Because of this, I do not believe Regina's relationship with Snow is indicative of a mother-child relationship and therefore does not reveal a lot about her maternal instincts.

We see the difference in maternal instincts between Regina and the Evil Queen when the Evil Queen traps Regina and Emma in a hidden world and impersonates Regina (Schwartz, Fong, \& Lynch, 2016). The Evil Queen carries a lot of love in her heart for Henry, even if it does not always show. Rumplestiltskin brings this up when he sees her newest plan and reminds her that love is weakness. "Love can be weakness, but it can also be a weapon, and I'm about to use that weapon on my son," the Evil Queen replies. She has to justify her love as something 
violent and not maternal in order to maintain Rumplestiltskin's respect as a fellow evildoer.

Regina witnesses the Evil Queen's encounters with Henry when she tells him to pay attention to his posture and gives him romantic advice, and she realizes that she is a much better mother than the Evil Queen ever was. "I'm afraid to raise Henry alone..." she tells Emma. "But every time I see him with Mommie Dearest over there, it's just a reminder of the horrible mother I could have been.” Regina's allusion to the novel-turned-movie about Joan Crawford abusing her daughter is indicative of what she thinks of the Evil Queen's parenting potential.

Emma typically falls somewhere in the middle of the spectrum on her maternal skills. She gave Henry up for adoption and has no experience caring for a child or being cared for by a parent, as she was also given up for adoption. But, even lacking this experience, Emma is very protective of Henry and often stands up to Regina for him. Emma reroutes her entire life to stay in Storybrooke and look over Henry just to make sure he is being cared for properly by Regina. Overall, OUAT recognizes a very particular type of maternity as good. Specifically, good maternal instincts are those that cause women to act based on their emotion not logic. Good maternal instincts are those that nurture and encourage others while simultaneously looking out for their best interests. Under this definition, Regina is not very maternal when we see her in the first season, though she does improve her skills by the time she splits herself in half.

In addition to strong maternal instincts, female characters are expected to be selfless in their actions. If they are not, they run the risk of being seen as evil and dangerous. Selflessness comes in many forms. For Mary Margaret/Snow White, being selfless means accepting that she is meant to act as a moral compass for others. Snow must put her feelings and desires aside in order to do what is best for Prince Charming and his kingdom (Kitsis, Horowitz, \& Hemecker, 2012). She is also expected to not take the "cure" for love that she received from 
Rumplestiltskin because the dwarves tell her that it is for the best. Mary Margaret is forced to make the tough decision to not pursue her feelings for David, even though he is the one "committed" to another. She has to repeatedly tell him no, and then when they do engage in an affair, she is the one to continually urge David to tell his wife the truth. Both lapses in judgement - the "cure" and the affair - create extremely problematic circumstances for Snow White/Mary Margaret that she must overcome and endure shame, humiliation, and heartbreak before being accepted by her community once more.

When Emma is the Dark One, she has to deal with the effects of her family just believing that she is being selfish (Kitsis, Horowitz, \& Tirone, 2015). Emma's family and friends stumble onto one of Emma's dreamcatchers that she used to take their memories, and they learn that Emma manipulated Henry's crush in order to break his heart in Camelot. They only get a snapshot of this memory, however, so they do not see that Emma did so to be able to free Merlin from his entrapment and get closer to ridding herself of the darkness. Emma attempts to talk to Henry about it but is confronted by Regina instead. Regina yells at Emma fervently, deeply angered by the turn of events, seeing only the evil actions without any of the good intent behind it. Emma responds almost devoid of emotion and reminds Regina of her days as the Evil Queen. Regina: "If I'm the one on the moral high ground, you've fallen quite a ways, Ms. Swan." Emma: “Don't 'Ms. Swan' me. We've been through too much. You know I would never have done that to Henry if I didn't have a good reason."

Regina: "'Good reason.' You know, that's exactly what my mother said to justify what she did to Daniel."

This moment is powerful for a few different reasons. First, Regina's use of "Ms. Swan" is purposeful and draws a response from Emma because it is the moniker that Regina used when 
Emma first came to town and the two were sworn enemies, fighting over their only son. Years have passed since and the two have been on a first-name basis for quite a while. By calling Emma "Ms. Swan," Regina is letting Emma know that she is on the path to becoming a fullblown enemy again for hurting their son. This moment is also powerful because Regina's mother, Cora, is easily considered one of the more heartless villains in OUAT. When Regina references what her mother did to Daniel, she means that Cora killed Daniel when she found out the two were going to run away and elope, believing that her daughter would be much better off marrying the king and wanting to socially advance herself through the union. Regina is telling Emma that her actions are comparable to Cora's selfish deeds. Although Emma was actually able to get a step closer to getting rid of her darkness through her actions, her family only sees the selfish side of it, finally certain that she has become fully evil because of it.

As the Evil Queen, Regina is no stranger to being selfish. A great example of this is when Regina kills her father. He is trying to convince her to give up on casting the curse so he can live, but Regina tells him through tears that she wants to be happy and rips his heart out. In that moment, Regina was more concerned with finally achieving her own happiness than her father's life. One other notable moment was when Regina told her son that she had to work on a Saturday and left him home alone. Instead of working, however, she checked into the local bed and breakfast with Graham, her friend with benefits. She hinted that this was a regular occurrence for the two. While this act alone does not make Regina evil, it does make her look like a bad mother and encourages some slut-shaming from the audience for engaging in sex rather than caring for her son. Sexuality as a form of selfishness is a trend for the evil version of Regina, as we see later in the series. When she splits from herself, the Evil Queen is focused on seducing Rumplestiltskin because she is lonely and wants his attention to feel better about 
herself. The Evil Queen also talks about another male character in a sexual manner to Regina, but Regina tells her that she's "not here for your perversions," proving that the blatant sexuality of the Evil Queen is not accepted by even the "good" version of herself.

When women in OUAT shift their focus to themselves or even seemingly shift their focus to themselves, they are coded as evil. This is because being selfless goes hand in hand with being maternal. It is difficult to truly be a motherly figure when you care more about yourself than you care about others. If a woman is making a decision based on her own wants and desires, she is not considering the desires of others, meaning she does not care about how others feel. This is why Mary Margaret is generally considered to be a good character whereas Regina is generally seen as evil.

For male characters, the defining trait that determines good from evil is bravery. Typically, discussing any sort of emotion or feeling is relegated to female characters. Male characters are usually discouraged from actions like crying and deep discussions of emotional issues. This arc helps create a clearer boundary in discussing emotion for male characters. Fear is acceptable for even the most masculine characters, as long as it does not completely impair the character's ability to fight and overcome the fear by being brave. This is showcased in "The Tower" where Prince Charming has to face his greatest fear of being a bad father (Hull \& Hemecker, 2014). At first, Charming believes that to be a true hero, he must suppress all fear and be brave for his wife. He quickly learns that this tactic is ineffective and that to overcome the barrier he has created with his fear, he must first admit that it exists. As Regina tells him, "When we face our deepest fears, our true courage comes out."

Henry idolizes his grandfather, Prince Charming. He often asks for lessons on sword fighting and asks about FTL because he wants to be chivalrous and brave when he grows up, just 
like Charming. He already understands at a young age that bravery is a huge part of what it means to be masculine and a hero. This is why when Henry is faced with Peter Pan and the Lost Boys in "Heart of the Truest Believer" he does not back down. Instead, Henry confronts the boys that could easily harm or kill him. Unfortunately, this makes Henry a target for Peter Pan's manipulative tactics. An example of Pan preying on Henry's hero complex is when Henry is provoked into fighting another Lost Boy (Boylan, Thomsen, \& Amiel, 2013). Pan encourages him to fight with a real sword instead of a stick, and Henry listens. He ends up cutting the other boy in the process. Although Henry feels momentarily guilty, he begins to feel excitement over the victory after Pan and the others cheer for him. Henry misinterprets what bravery is because of his young age. As he grows in the series, so does his understanding of bravery. An example of Henry's bravery later in the series is seen when he stands up in a public park in New York City and begs the public to help him get his family back by making a wish in the fountain (Kitsis, Horowitz, \& White, 2016). Henry is desperately afraid of failing and losing his family, but he pursues even the craziest solution to the problem at hand, even if he ends up looking ridiculous in front of his new girlfriend, Violet. In the end, Henry is rewarded for his bravery and gets both his family back and the girl.

Rumplestiltskin is a great example of what happens when male characters lack bravery. Rumplestiltskin is often characterized throughout the series as a coward. Before Rumplestiltskin transforms into the Dark One, he is drafted for the war, but he shoots himself in the leg to escape war. This act of cowardice costs Rumplestiltskin dearly, as his wife leaves him and the town sees him as a traitor. Even as the Dark One, Rumplestiltskin cannot escape his status as a coward. He uses his magical abilities as a shield, protecting him and those he loves from harm. Without it, he feels small and vulnerable. He is willing to make any deal or take any way out of 
a fight rather than actually confronting it. This is clear each time he is up against Merida (Chambliss, Chun, \& Hemecker, 2015). Even after Belle tells him that she believes in him and knows he can be a hero, he does not believe her and plans to run away. She is the only thing that stops him from leaving town, and even then, she is barely able to do so. When Belle first kisses Rumplestiltskin in FTL and begins to break the curse of the Dark One, he stops her and yells at her, thinking she is doing this to purposely weaken him (Espenson \& Cheylov, 2012). "I knew this was a trick," he tells her. "I knew you could never care for me. Oh, yeah. You're working for her [the Evil Queen]. Or is this all you? Is this you being the hero and killing the beast?" He ends up locking her in a cell for trying to trick him. Later, when he visits her in the dungeon, she calls him a coward. "I'm not a coward, dearie," he responds. "It's quite simple, really. My power means more to me than you." Though this may be true, Rumplestiltskin only truly acts brave once and that is to save Belle's life (Chambliss, Chun, \& Hemecker, 2015). Even so, he still uses residual magic to save her life, avoiding any sort of physical confrontation with Merida. Rumplestiltskin's use of magic when saving Belle's life is considered less masculine than a brave act by Charming or even Henry because of the means he uses to achieve the act. By this, I mean that $O U A T$ codes specific skills, such as magic use, as feminine and some skills as masculine. Using magic is a very feminine act, as it is something that is done almost exclusively by women, aside from Rumplestiltskin and other minor male characters throughout the series. The only other main characters that use magic are female, like Regina and Emma. Magic, for the most part, is non-confrontational. It does not require physical strength or ability. Instead, magic relies on emotional control, which is why Emma briefly lost control of her magic in the first arc I examined. As emotions are coded as feminine, using magic - a skill that relies on emotions - is also considered a feminine practice. This is not the only time that Rumplestiltskin engages in a 
feminine act, however. Rumplestiltskin often uses a spinning wheel to turn straw into yarn and later, after he is imbued with magic, gold. Spinning is a feminine act, as it is one of the first steps in creating fabric for things like clothes. Spinning yarn takes a delicate touch and patience, traits that are coded as feminine.

Methods of fighting are the skills most gendered in OUAT. In addition to magic, there are other physical forms of fighting that are coded as both masculine and feminine. Sword fighting, for example, is a very masculine skill to have. This makes sense as the sword has historically been a phallic symbol, an extension of true masculinity. Charming, the epitome of masculinity, is excellent at sword fighting. He is so excellent that he defeats a dragon when not even a highly-experienced group of knights could do so. As I mentioned previously, Henry is eager to learn from his grandfather and quick to pick up a sword when urged by Peter Pan. Emma also dabbles in sword fighting, learning quickly that her gun is not very effective against fairy tale characters. As Emma is not an overly feminine character, it makes sense that she would pick up a masculine skill such as sword fighting.

This is contrasted with Snow White's superior ability with a bow and arrow. Occasionally we see Snow with a sword or Charming with a bow, but typically they stick to their preferred weapons. A bow is a more passive weapon, one that is most effective from far away, which makes sense for a more passive character, like Snow White. Sword fighting requires the person wielding the weapon to be close to the target, directly in harm's way and requires the strength to lift and use the sword effectively. It is direct and confrontational. Shooting a bow, on the other hand, is about patience and strategy rather than brawn, traits often seen as more feminine. The bow is also a more deceptive weapon than the sword, allowing the shooter to 
sneak up on the prey and dispatch it from afar, a characterization that is often applied to female characters.

The practice of gendering traits and skills in $O U A T$ is extremely problematic. Much like coding appearances as good or evil, valuing certain traits over others encourages the audience to do the same. This is especially a problem when these traits and skills have historically been lauded as good in other fairy tales and media. For example, viewing a strong maternal instinct as good is the basis for many different fairy tales and continues to enforce strict gender norms (Tatar, 2003). When individuals do not fit into these norms, they are cast from society as being lesser, especially if they are women or more feminine. For the most part, masculine traits and skills are the most valued in society, as long as they are held by men. Women are valued if they are caring for others, such as the men around them. Women are expected to make sacrifices and think of others before themselves, just like Snow White was expected to give up her love for Prince Charming because he was supposed to be with someone else (Tigelaar \& White, 2011).

\section{Power Differences}

The male characters in OUAT have much more access to power and autonomy than the female characters. For men, power is not an indication of a good or evil status; it is just a fact of life. The entire first arc surrounding David/Charming is focused solely on his autonomy and control over the situation. He has a choice to make between the two women as both David and Charming, something that many different characters remind him of repeatedly. Although he seems burdened by this choice, he has more access to power than many of the other characters in OUAT. He is concerned with making the correct choice, while characters like Mary Margaret are rarely given moments of agency. Mary Margaret did not choose the affair with David, as she had clearly and consistently told him no on several occasions. The only time that she faltered on 
this was when David told her that he had already left his wife. Instead of respecting her decision to stay away from him, David put himself in situations where he was near Mary Margaret, even after she asked him not to. One example of this was when Mary Margaret went out into the woods before a bad storm to release a bird into the wild (Kitsis, Horowitz, \& Hemecker, 2012). David asked if she wanted him to go with her, and she told him no. He disregarded her wishes and went after her anyway. After the affair begins, Mary Margaret is very clear that she wants David to tell Kathryn the truth, and he agrees. At this point, Mary Margaret thinks she is choosing to be with a man who is intent on leaving his wife and being honest with her in the process. David goes back on his word, however, indicating that he believes his choice is more powerful and meaningful than Mary Margaret's because hers is easily discarded.

Charming also has a good deal of power over the situation with Snow White and Midas's daughter. After Charming thinks that Snow White does not love him, he still decides to break the promised marriage to Midas's daughter and soon finds that she did not want to marry him either. She also loves another, but her love was accidentally turned to gold by her father.

Charming decides to accept a quest to an enchanted lake to retrieve water that could save her true love. At this lake he encounters a siren, famous for luring men to their death by seducing them. Charming overcomes his desires, even as the siren takes the form of Snow White. He proves that he is more powerful than even his strongest desires and can choose to suppress them when required.

There are other small moments that highlight this power as well. During one of the many episodes that I watched, I realized that the coat of arms that Snow and Charming have once they are married is the same as King George's coat of arms. This means that even though Snow White is a princess by blood and the kingdom that they eventually rule over is rightfully hers, the 
outward symbol of their power belongs to Charming. I find this particularly interesting because this coat of arms does not even truly belong to Charming, as it is one he inherited by posing as the true prince and belongs to a king that he despises and wanted him dead.

Henry also understands that as a boy, he is entitled to a certain amount of power. Consequently, even Henry has more power than the female characters in this analysis. The whole story begins when Henry steals Mary Margaret's credit card and pays for adoption records to find his birth mother. He then runs away to Boston to find Emma and forces her to bring him back home by threatening to call the police and claim she kidnapped him. Henry also dictates what he wants to do when he wants to do it with little regard to his parents' rules and regulations. Surprisingly, the only time Henry is punished is when Regina is still fully evil and trying to keep him away from Emma for fear of losing him. Henry does not respect the punishment's boundaries, however, and easily sneaks out once Regina's back is turned.

In one dangerous situation after another, Henry defies authority and demands things from those around him with little to no consequences, and he is fearless in his actions. While Henry's attitude of fearlessness in "Heart of the Truest Believer" is likely a result of his young age and innocence, his experiences support this notion of invincibility. He is not harmed once by his older enemies, the Lost Boys and Peter Pan, even though he directly defies their orders and is unable to protect himself in any way. Even after Henry hands his heart over to Pan, a willing sacrifice, Henry survives the encounter and is not harmed in the process. This sends a message to viewers that any attempt of heroism is rewarded, especially for a man. It sends a message that it is acceptable for masculine individuals have more access to power, regardless of age.

Throughout the series, Henry continually acts without consulting others or thinking of the potential consequences. The first time that Henry is truly affected by the negative consequences 
of his actions is in "An Untold Story." Henry realizes that it would be his fault if his family is stuck in another realm forever, and it is a hard truth to swallow, but he takes responsibility for it and finds a way to fix his problem (Kitsis, Horowitz, \& White, 2016). This is an extremely important moment in understanding how masculinity is understood in $O U A T$. The audience learns along with Henry what it takes to be a true hero - something that is different than being a heroine. Being a male hero means believing in yourself even after you have made a mistake and learning from your mistakes. It means having the power to take control over the situation and finding a solution to the problem at hand.

Rumplestiltskin's level of agency vastly changes after he becomes the Dark One. Before he becomes the Dark One, Rumplestiltskin has little to no power or agency in society, much like the women. He is allowed to be a member of society only if he keeps to himself and does not attempt to make waves of any sort. This is because he has committed the unthinkable act of deserting the war and is labeled a coward for it. His lack of bravery has him labeled as feminine, so he is treated as such. It is not until after he becomes evil that Rumplestiltskin gains access to power. As the Dark One, Rumplestiltskin has a hand in every story, making deals and using his magic to provide solutions to others' problems. For example, when Regina had trouble casting the curse, Rumplestiltskin told her he would help if and only if she promised to give him a good life in the new world as well as obey his every command as long as he says please. Regina agrees, believing that he will not remember this conversation, but he does remember and is able to control Regina even after she curses the entire land. In Storybrooke, he reminds her that she does not have any sort of power over him, even after he is arrested for assaulting Moe French. "Now that we're being honest with each other, let's remember how things used to be, shall we? And don't let these bars fool you, dear. I'm the one with the power around here." There are 
times where Rumplestiltskin lacks the power to accomplish his goals, and he is forced to seek out help from Emma or others, but these times are far and few between. More often than not, characters like Emma and Regina ask Rumplestiltskin for help with a magical issue. It is rare that Snow White or Prince Charming ask for his help, but it does happen on occasion.

Unlike men, women are not given access to power or control. If they are given any sort of power, their access is extremely limited and mostly superficial. For women, seeking more power or autonomy is a dangerous and evil act only done by women like Regina and her mother Cora. Instead, women must accept and be content with their lack of power to be considered good. Even though she seems to have a bit of autonomy and agency, Snow White lacks power throughout the series. In FTL, Snow is constantly on the run from the Evil Queen and her soldiers, limiting where she can go. In addition to this, she must be wary of individuals who would turn her into the queen just for the reward money, limiting her ability to make money and provide for herself. As mentioned previously, when she marries Prince Charming, she takes his crest as her own, even though it is does not actually represent his true family. And, most notably, in Storybrooke, Mary Margaret's actions and decisions are not taken seriously, especially by David who constantly manipulates situations in order for Mary Margaret to agree to the affair. Mary Margaret constantly tells David he needs to make a choice between her and Kathryn, even after the two begin their affair. She wants him to tell Kathryn the truth, but he does not want to tell her about the affair for fear of hurting her. Mary Margaret makes her opinion clear and tells David that honesty is the best option and that he needs to choose which path to take, but he refuses to listen to her, causing the affair to tarnish her reputation and leaves David relatively unscathed. Mary Margaret confronts David about this (Espenson \& Underwood, 2012). 
Mary Margaret: "Why didn't you tell her?"

David: "I thought we could spare her feelings."

Mary Margaret: "Right. You thought. Not we. You. And we discussed this."

David: "I didn't want anyone to get hurt."

Mary Margaret: "Now everyone is hurt. We had an understanding. We had an agreement. But you not only lied to her, you lied to me."

Throughout this discussion, we can see how powerless Mary Margaret feels about the situation. She explains that she had trusted David to follow through with what they had agreed upon, but he did not, instead opting for his own solution to the problem which ultimately caused more problems.

Snow White also has little choice over how to deal with her love for Prince Charming in "7:15 AM." She attempts to stop him from marrying by sneaking into his castle with the intent of professing her love, but she is stopped by the king and manipulated into telling Charming to marry the other woman (Kitsis, Horowitz, \& Hemecker, 2012). King George tells Snow that if she tells Charming the truth, he will kill the prince, which really leaves her with no choice. If she tells Charming that she loves him, she risks his life, something she is not willing to do because she does love him so much.

The one time that Mary Margaret truly had autonomy and the power to choose her course of action is in the episode "The Miller's Daughter," and she chose to do something heinous. Mary Margaret lit the candle over Cora's heart because Rumplestiltskin challenged her love of her family. She chose to go after Regina and try to stop her because David appeared at the vault and made her realize her mistake. The only time that Mary Margaret had to decide on her own without the help or urging of man was in the vault with Regina. When she was caught standing 
over Cora's cursed heart by Regina, she chose to use her good image, her maternal image, to carry out Cora's murder through her own daughter (Espenson \& Hemecker, 2013). She has Regina believe that she might finally attain the one thing she's always wanted - her mother's love. In this moment, Mary Margaret is manipulative and cruel, and no one besides Regina seems to notice.

Emma, who seemingly has access to a lot of power due to her status as sheriff, magical abilities, and role as Savior, is actually quite limited in her actions as well. Throughout the series, we learn that fate or destiny has determined most of Emma's actions over the years, even before she stepped foot into Storybrooke. Her childhood best friend is actually the child her parents cursed with all of her potential darkness. Her first love and Henry's father is actually Rumplestiltskin's son and he begins Emma's journey to breaking the curse. When Emma gives her baby up for adoption, Rumplestiltskin is the one to make sure he is adopted by Regina Mills.

Even as the Dark One, Emma's actions are influenced by others. Although Emma possesses the most powerful magic and is capable of the evilest of feats, she does not seem to have much control over those around her. Emma attempts to bribe Zelena, Regina's sister and the Wicked Witch of the West, but she is unable to make a deal with the witch (Kitsis, Horowitz, \& Underwood, 2016). This is very unusual for someone with such a vast amount of power, such as the Dark One. Later, Emma forces Rumplestiltskin to become a hero and save his true love in order to retrieve Excalibur for her, but before he actually pulls the sword from the stone, he makes a deal with Emma, which she accepts (Chambliss, Chun, \& Hemecker, 2015). I found this to be very odd considering Emma could easily just threaten to kill Rumplestiltskin's true love in order to manipulate him. Instead, Emma chooses to accept the terms of his deal, giving up her power over the situation. Even as the most powerful person in Storybrooke, Emma did 
not truly have access to this power. This lack of actual power is highlighted as everyone gets their memories back and Hook finds out about also being a Dark One.

When Hook learns of his new dark powers, he leaves Emma behind and finds a way to bring all the past Dark Ones back to life and to Storybrooke (Kitsis, Horowitz, \& Tirone, 2015). Emma, on the other hand, has been temporarily stripped of her magic by a bracelet that she had used on Zelena, and her family refuses to free her of the trinket even after knowing her entire plan was to rid both herself and Hook from the darkness. She reaches out to Henry, thinking that he will listen to her, but he refuses. "I thought you were the one person who would understand," Emma says to Henry, surprised by his actions. Henry responds, "I thought you were the one person I could trust." Slowly, her family begins to trust her, but she is forced to agree to their terms in order to regain some of her lost freedom. For example, Henry agrees to remove the bracelet only if she vows to not use her magic anymore.

Throughout Emma's entire journey as the Dark One, she had little to no control over the situation. Emma was more concerned with not severing the relationships she had with her family and friends than ruling over people, making her weak in the eyes of others. This meant that she listened to her family faithfully in Camelot with one exception - when she transformed Hook into the Dark One. She later regretted this decision, as it led to his eventual death at her hand. In Storybrooke, Emma lacked the intimidation that usually accompanies the Dark One, making her more vulnerable to manipulation. Even though people like Rumplestiltskin and Zelena did not view her as a huge threat, her family did not see her as herself anymore. This put Emma in an odd sort of limbo where she was not fully embracing the evilness inside of her, but she was considered too evil to be a part of her family anymore. Regardless of how many times Emma tried to tell her family and friends that she was the same person as before, no one seemed to 
believe her and spoke of her as if she was lost and needed to be found. Emma did not even have the power to self-identify at this point.

The Evil Queen, who has the most access to power through her title as queen and her magic, is still disrespected by most of the people around her. None of her citizens have a high opinion of her as queen of their kingdom, and most see her pursuit of Snow as a witch hunt. Rumplestiltskin regularly shows Regina that she's ineffectual as queen and mayor and at just being evil in general. For example, when Regina had trouble casting the curse in FTL, Rumplestiltskin told her he would help if and only if she promised to give him a good life in the new world as well as obey his every command as long as he says please. Regina agrees, believing that he will not remember this conversation, but he does remember and is able to control Regina even after she curses the entire land.

Although Regina went to incredible lengths to separate herself from her dark side, her family and friends still constantly conflate the two (Kitsis, Horowitz, \& White, 2016). For example, when someone tries to leave town but cannot because of a spell someone cast, Emma tells Regina that it is like the protection spell she used when she first created Storybrooke. This is really interesting because for other characters like Emma and Snow, whenever they would commit a dark or evil act, their friends and family were quick to dismiss it as an act by someone else (i.e., it was not the person they know and love; it was a separate entity). But, when it comes to Regina, it is much more difficult for even those close to Regina to separate her from her previous evil actions, even after she literally separates herself. Similar to Emma, Regina does not have the power to self-identify as good or evil. Instead, those around her take it upon themselves to decide where she falls on the spectrum. 
Women are expected to be content with their low level of control and power, but $O U A T$ is not quite so blatant in sending this message to its audience. Instead, women are told to embrace love in the place of power. Regina's father highlights this very message (Kitsis, Horowitz, \& Beeman, 2011). "Power is seductive, but so is love," Regina's father tells her to try and convince her one last time to pursue love instead of revenge, as it will make her happier. Men are not given this same dichotomous message, however. Men are allowed to have power and autonomy, while also embracing love as another force of good. A common theme throughout the series is that the evil characters view love as a form of weakness, and Regina is no different. She views love as a potential target for taking down others. For example, she was victorious in her fight with Maleficent because instead of coming after the woman, she aimed her fire at Maleficent's pet. Maleficent admits defeat to save her beloved pet, and Regina leaves with the curse in hand. Her obsession with power is one of the things that leads her to kill her own father. After he finds out what it takes to cast the curse, Regina's father urges her to find another way to be happy and give up on the curse. The Evil Queen responds, “All I've worked for, all I've built will be gone. My power will disappear. They already think I'm nothing." Regina is attempting to explain to her father that she feels as though the only thing she has left over the people in the kingdom is power. They do not respect or love her and never have. If she gives up fighting Snow White, she is handing her power, her freedom, over to the very girl she despises.

Her father's quote highlights an important theme throughout the series regarding power. To good characters, true love is the ultimate goal. Love is power and strength. To evil characters, however, love is weakness. It can strip an individual of true power because it gives their enemies a perfect target. If you do not love anyone or anything, no one can hurt you. As I 
watched Regina and others discuss love as a form of weakness, I realized that this is a very defensive position, especially for characters that constantly seem on the offense. They see love as a weakness because that is what they draw from their own experiences; they lost someone they loved and felt helpless. Instead of putting themselves through that pain again, these characters find a way to protect themselves - by gaining power and using it against others before others can hurt them first.

Regina, for example, was once deeply in love with Daniel, a stable boy. Her mother did not approve of the relationship and instead arranged for Regina to marry the king, making her queen of the entire kingdom. Regina and Daniel planned to elope and ignore the king's proposal, but Snow White found out and told Regina's mother about the elopement. Regina explained to Cora that she was in love with Daniel and wanted to marry him instead of the king. Cora told Regina that she only wants what is best for her daughter, and for a second, Regina thought that Cora may allow her and Daniel to marry. Not a moment later, Cora ripped out Daniel's heart and crushed it in front of Regina. Cora then forced Regina to marry the king against her will. For Regina, her love for Daniel was her weakness. Cora had used magic to punish Regina previously, and that did not seem to faze the girl. It was not until Cora hurt the person Regina loved that she truly hurt Regina. Cora tells Regina that love is weakness and then proves her point by taking away the one person who Regina loved.

Nimue, the first Dark One, experienced a similar loss, leading her to seek power over love. Nimue appears to Emma as Rumplestiltskin has been and explains that she became the first Dark One by using her newly acquired magical powers to kill the man that burned down her village and killed her family (Espenson \& Tirone, 2015). Nimue urges Emma to kill Merlin so he cannot take this power from her: 
Even when you love someone, you have to say, 'No, this is mine. You can't take it away from me.' And if they don't listen, if they try to stop you from being you, then you have no choice. You have to kill them.

Nimue is the original Dark One - a magical being that is characterized as the most evil that ever was, yet her words are not spoken out of pure evilness; they are spoken from a place of pain and trauma. Nimue is discussing the importance of holding onto your identity and your power because she understands firsthand what it is like to lose everything. Later, she emphasizes the importance of not becoming powerless again. This quotation is especially intriguing because the characterization of Nimue is what many think a feminist looks like, a woman who is power hungry and does not care who she hurts in the process of achieving her goals. The show dismisses this brand of feminism by having Emma overcome the darkness and save Merlin, but it does not offer an alternative form of feminism. Instead, Emma is completely reliant on those around her to continue guiding her on the right path - choosing love over her power.

As much as the show professes that true love is the most powerful thing in the world, it does not equate to agency or autonomy. These things are specifically kept from women for various reasons, but the most prominent reason that women seem to lack power is because women are too emotional to be in control or have access to real power. The very thing that makes women more feminine and good makes them unfit to be in charge of anything. The first arc I examined for Emma is a perfect example of this concept. This arc tackles one of the most stereotypical depictions of feminine individuals - the emotional, out of control, crazy person. Often, feminine individuals are viewed as less capable because they are more in touch with their emotional side than their masculine counterparts. When trying to express said emotions, these individuals are depicted as crazy, irrational beings that are incapable of making good decisions. 
As Emma's emotions are connected to her magic, there is an added element to the equation.

Emma was viewed as an actual danger to society due to her unstable emotional state.

Though some attempt to reach out to Emma in the beginning, such as her boyfriend and her son, both are unable to reach her and help calm her magic with reason and logic. Even when Emma decides to give up her magic, an essential part of her Savior identity, her parents are ambivalent to the situation, sitting around the kitchen drinking tea. The only person that attempts to actually help Emma work through her fear is Elsa, but even then, after their talk, Emma is expected to be fine and back to "normal." This is extremely problematic because it reinforces the idea that being emotional - something that is strongly associated with the feminine gender - is a negative quality and can cause even the best of individuals to lose their way.

Throughout this arc, people are constantly reiterating that the choice of whether to keep her magic or not is solely Emma's and that she will make the right decision. This means that even though her family and friends are acutely aware of Emma's emotional state, they still fully expected her to make a life-altering decision based on logic and reason without any other options present. Although everyone seems to agree that the choice is Emma's, in reality, Emma is given very little autonomy over the situation and forced to believe that there is no other option than to get rid of her magic if she wants to keep her loved ones safe. As the Savior, this desire is not just important to Emma, it is a part of her identity. Emma represents the exact reason why women are not given power and must instead rely on carefully honing in their emotions without becoming completely devoid of emotion, like Regina does as the mayor.

\section{Conclusion}

Throughout my analysis I found that $O U A T$ reinforces the same strict gender norms that are commonplace in fairy tales. The series does this covertly through characters' appearances, 
traits and skills, and access to power. The added element of good versus evil in the series accentuates these norms by explicitly labeling individuals as good or evil. When someone is labeled "good," their entire persona is celebrated. When someone is labeled "evil," everything about them is vilified. Women are scrutinized more than men, especially regarding their autonomy. Overall, OUAT does not challenge the hegemonic gender norms typically found in fairy tales.

OUAT promoted the series by claiming we would see all of our favorite classic fairy tale characters in an entirely new way with new stories to be told, but the show has failed to do just this. While some of the storylines have changed, the underlying messages about gender and power have not. Instead, these same messages of what makes someone good or evil based on their gender have just become more covert and entrenched in the storyline. This is extremely problematic because many see this series as a great example of feminism and as a "fix" to the problematic tales they have grown up with. This is not the case. While the series does have a female character as the central hero, the underlying messages about her and the other main characters are not different from the traditional tales. Passing these characters and stories off as inherently different makes it easier for the audience to consume the underlying sexist messages and continue to expect these strict gender performances in all aspects of life beyond media consumption. 


\section{CHAPTER V: DISCUSSION}

Throughout my analysis of $O U A T$, I discovered that the show reinforces typical gender norms and performance in three different ways. First, OUAT regulates gender performance through appearance. Second, the show codes specific traits and skills as masculine or feminine. Finally, OUAT limits the access to power, control, and autonomy for female characters but not male characters. OUAT relies on traditional femininity and hegemonic masculinity to dictate what good and evil characters look like throughout the series. A delicate appearance for women (i.e., light colors, floral prints, light makeup, small and simple jewelry) indicates a character that has an innate tendency for good, such as Snow White. Overly sexual or defeminized female characters, such as the Evil Queen or Emma as the Dark One, indicates a character that has an innate tendency for evil. For men, anything that hints at femininity is an indication of evil tendencies.

Different traits and skills are also used to reinforce gender norms. An example of this is how women are expected to be maternal in every aspect of their lives. They are also expected to act selflessly. When a woman does not exhibit these traits, she is often demonized and seen as an evil character. I found similar expectations for men regarding bravery. If men are not brave, they are not truly considered men. They are seen as lesser beings, like Rumplestiltskin. Even certain skills are gendered throughout the series, creating very rigid boundaries of gender performance for the characters.

I also discovered that analyzing the access to power and control for different characters is vitally important in understanding how $O U A T$ depicts good and evil, specifically in women. Men are automatically granted access to power, and this has no bearing on whether they are coded as good or evil. Even Henry, who is a young boy at the beginning of the series, is given 
more power than the adult female characters. Women, on the other hand, are not given access to power or control. Instead, they are told to focus on love as a source of power rather than seeking any sort of autonomy or agency. If women reject this idea and seek power, they are coded as evil characters and treated as such. OUAT uses the good versus evil theme to reinforce problematic and strict gender norms throughout the series.

In this study, I found that $O U A T$ reinforces the same problematic gender norms that traditional fairy tales do in almost identical ways, specifically in the six main characters that I analyzed in this study. This is a very important finding because, on the surface, OUAT seems like a feminist retelling of classic fairy tales. The show highlights a female hero, Emma Swan, and seems to care about portraying women as multi-dimensional and independent beings. For example, in the episode "Snow Falls," Charming is hit by Snow White, as she tries to escape being captured for robbing him (Tigelaar \& White, 2011). He is quite surprised at her appearance and exclaims, "You're a girl?" Snow White corrects him by telling him that she is a woman before she escapes once more. This dialogue is important in cultivating a feminist image because it highlights the importance of taking women seriously, as they can be just as strong or dangerous as men.

The promotional materials and interviews for $O U A T$ are also centered on the idea of a female hero at the forefront of the series vying against a female villain. In most of the promotional photos, Emma is situated in the middle of the main cast, usually clad in her trademark red leather jacket with a sword clutched in her hand. Jennifer Morrison, the actress behind Emma Swan, described Emma as "kickass" and a "tough chick" (Masters, 2011, para. 7). Emma is not the only character that was described as such before the show aired, however. "I think this is the first time anyone's ever shown Snow White swinging a sword — and she's 
pregnant! - and ABC was cool with that," said Kitsis of the pilot episode (Masters \& Mitovich, 2011, para. 4). While $O U A T$ was not advertised explicitly as a feminist show, it certainly emphasized female characters and their access to power and other masculine traits, such as the ability to wield a sword. The problem with this is that the show does not follow through with these seemingly feminist attitudes.

OUAT makes a habit of pointing out the powerful women in the series, as can be seen in the examples above, leading viewers to the conclusion that this is an example of feminist media. This series relies on covert forms of oppression to reinforce hegemonic gender norms among its main cast. Covert or subtle sexism is very problematic because, by nature, it is often hidden and cannot be seen from just one interaction. Instead, it usually takes someone noticing a pattern of behaviors over time to see the underlying sexist tendencies. A great example of how this operates in real life can be seen through microaggressions. Microaggressions are small but common interactions that have an underlying discriminatory or hostile nature against an oppressed group (Nadal, Hamit, Lyons, Weinberg, \& Corman, 2013). While microaggressions are often cited when talking about oppression based in race or sexuality, they also apply to gender. For women, microaggressions tend to fall under a few themes, including restricting gender roles, ignoring sexism, and female invisibility (Sue, 2010). While microaggressions are hostile in nature, they often go unnoticed due to their frequency in everyday life.

Microaggressions are just one example of how covert sexism operates in society, and while they are present in the interactions that I examined, they do not encompass all of the issues that I found in my analysis. Although the female characters that I studied may claim to be strong and independent and seem at the center of all the action, the underlying power structure and gender expectations are just as sexist as in the original tales, bringing us back to the original idea 
of a fairy tale as a myth. Campbell (1991) is very clear that women cannot be at the center of a hero's journey, and he might have a point after examining the main characters of OUAT. Murdock (1990) notes that a woman can be at the center of a hero's journey, but it may not look exactly the same as a man's journey, as she has restrictive gender norms to negotiate along the way. This does not seem to be the case with Emma, however, as her story, actions, and relationships all remain the same throughout the series. Instead, it seems as though one of the more minor characters I examined, Henry, is actually at the center of the hero's journey in OUAT. Even though Henry does not have as much screen time as the other characters in the series, his storyline is entwined in all of the others, and he is behind most of the action throughout. While this may make for an interesting storyline, it undermines the "empowered women" aesthetic that $O U A T$ set up in the beginning of the series.

While it is important to note that the characters I examined in $O U A T$ are more rigidly set in gender norms than we might think at first glance, it is also just as important examine why this might be the case. OUAT does not live inside a vacuum and is a small part of a much larger culture, a culture in which feminism is a nebulous concept that can take on various meanings. The first and second waves of feminism are relatively clear in their understanding of feminism and how it should operate, as these movements focused on the explicit forms of sexism in society, like embedded in the laws or in the workplace. The current "wave" of feminism is not as centrally focused as the past two, leading to an unclear message and fractured following (Banet-Weiser \& Portwood-Stacer, 2006; Coppock, Haydon, \& Richter, 1995; Genz \& Brabon, 2009). Post-feminism means many things do many people, but it is usually used to mark the current feminist movement. To some, post-feminism means a period after feminism, indicating that we no longer need feminism because we have already achieved all of the feminist goals from 
the previous waves. To others, post-feminism is synonymous with a third-wave of feminism, focused on intersectionality and the covert sexism that can still be found throughout society (Genz \& Brabon, 2009). With sexism more covert than ever and feminism fractured, it can be difficult for popular television like $O U A T$ to juggle everything.

In addition to coping with changing and unclear definitions of feminism, the creators and showrunners of OUAT also have to create a new and compelling story out of extremely famous and nostalgic tales. Most everyone who sits down to watch $O U A T$ comes into the experience with their own expectations of what they will see. This is because most everyone who watches the series has seen or read at least one version of the fairy tales portrayed. Fairy tales are such a staple in society for their moral lessons and appeal to children that many already know the storylines. If the series attempted to change anything too much from the original tales, it could put off their audience (or their parent company, Disney) and risk the success of the series. Not only do the showrunners have to consider the expectations of the audience, but they also must consider the needs of the audience. Campbell (1991) and Rowland (1990) both agree that fairy tales are typically stories reserved for children. They are relatively simple tales that almost always result in a happy ending. If an audience is tuning into a television show to watch fairy tales that they were fond of as children, they are likely looking for a story that is simple and easily digested; they are not looking for the drama of a procedural. This means that the showrunners must also be careful not to complicate the storylines too much in order to retain their audience.

These points are especially important when regarding the narrative paradigm that I used to analyze these characters. Fisher $(1984 ; 1985)$ explains that for a narrative to be persuasive, it must have both coherence and validity. If $O U A T$ attempted to tackle the issues highlighted in 
post-feminism or third-wave feminism, it would risk remaining coherent and valid to its audience, as the should could attempt to do too much and no longer make sense or it could alienate part of its audience and no longer be valid to those audience members. The same could be said for changing the original tales too much. If $O U A T$ attempted to change the characters at the core of the series, it would risk changing the tales that its audience already knows so well to a point where these stories are no longer coherent or valid to its audience. As OUAT did not stray too far from the original tales it became a very popular series among a wide audience, children and adults alike. This means that the series is a very persuasive narrative according to Fisher (1985), and therein lies the problem. The characters in this series act as symbols of gender performance, creating examples of how to properly act and the ramifications for crossing gender lines.

OUAT carefully balances nostalgic tales with modern values, but the series does little to challenge or change the hegemonic patriarchal ideology found within fairy tales. Gender is a very complex issue to tackle in popular culture, especially in a series like $O U A T$ for the reasons listed above, but it is essential to understand the potential problems that reinforcing hegemonic gender norms can create and why it is so important for series like OUAT to make a strong attempt at change. Unlike many popular Disney versions of fairy tales, OUAT is a television show, not a movie. This means that the showrunners have the potential to make gradual changes or small changes that would have a large impact on how gender in the series is portrayed. Even if the television show was not renewed beyond a single season, the showrunners would still have around 22 hour-long episodes to examine the storylines and characters in a way that challenges hegemonic gender norms. Television shows are not a static entity. They grow and evolve over time, unlike movies, allowing more opportunities for improvement. 
Audiences interact differently with a television show than they do a movie, as well. While movies can be consumed by an audience over and over again, there is no change in the storyline, characters, or general understanding of the film. Television offers a continuous visual story week after week, meaning that an audience has more opportunity to connect with the characters and invest in the storyline. This also means that the audience has more of an opportunity to learn behavior from the characters in the series than in a movie. Media help socially construct reality, and people learn different behaviors and values from media (Bandura, 2001; Glascock, 2015; Prieler, 2016; Te'eni-Harari \& Eyal, 2015). As a part of popular culture and media, OUAT has a certain authority that may be working to reinforce problematic gender norms. In addition to this, $O U A T$ is a live-action television show portraying characters and stories that have typically been explored through animation. While there is not much research on how an adult audience is affected by live action versus animation, it does have the potential to resonate with an adult audience by making these well-known tales more real in a way.

When an audience is impacted by and learns from a show like $O U A T$, it can be potentially dangerous because most television viewers are not focused on being critical consumers of media, especially when the media is used for entertainment purposes. An audience may be willing to accept the superficial representations of gender equality and feminism without realizing that these do not exist at a deeper level. For example, it is easy to watch the show and see women in positions of power around the town. Regina is the town's mayor, and Emma is the sheriff. From just this portrayal, it seems as though women are some of the more powerful characters in the show. It is not until the show is examined more closely that we learn how these women are often undermined or overshadowed by male characters like Rumplestiltskin. If the audience is willing to accept the covert sexism that occurs in $O U A T$, they may be more willing to 
accept in in their daily lives as well, as people learn from what they see in the media (Bandura, 2001).

While I discovered important and interesting themes regarding gender in OUAT that are certainly telling about how the show operates, there is still an abundance of research that can be conducted on the subject. One way of expanding this research would be to examine other television shows and movies that also deal with fairy tales to determine if these problematic gender norms are still present across all modern retellings of fairy tales or if it is more of an issue in OUAT than other shows. This would be an easy way to expand this research, as there are many recent television shows and movies based on fairy tales. Another way I could expand this research in the future is to analyze different characters.

In this study, I focused on the six main characters, but $O U A T$ has such a large and diverse cast of supporting characters that it would be very interesting to see if these themes are just as salient with other characters. There are some very unique supporting female characters that would be interesting to examine under a similar lens as I have in this study. Mulan, for example, seems to be a more masculine woman. She is a warrior, very experienced with a sword, and is even allowed to join Robin Hood's Merry Men. Mulan is also the first character on OUAT to be considered queer, eventually followed by Ruby (aka Little Red Riding Hood) and Dorothy from the Wizard of $\mathrm{Oz}$ universe. The large and diverse cast of OUAT makes it difficult to draw conclusions about the entire show from my analysis alone, as I was limited to six characters. Studying the supporting cast would reveal more about how the show portrays gender as a whole and how that might affect its audience.

Another area that could easily be studied in $O U A T$ is how race, class, and sexuality play into the gender norms. While the show does depict characters of different race, class and 
sexuality, they are far and few between, something that fans have criticized the showrunners for. It would be interesting to see if these characters are given the same expectations as their white, middle-class, straight counterparts. In addition to this, I would love to examine the stigma attached to being labeled as evil in $O U A T$ and how characters move past this label. Throughout most of the series, Regina has been trying to redeem herself from her past deeds as the Evil Queen but seems to have a very difficult time in doing this. I think it would be worth examining why it is so difficult for her character to move on from her evil past and why other characters are unwilling to let her do so.

OUAT is a successful show for a reason; it combines fairy tales from the past with intriguing and modern storylines. The series has an extremely large cast of characters with many different personalities, but what I found when analyzing the six main characters is disconcerting. With a wide audience of both adults and children, OUAT continues to reinforce the problematic gender roles of the past but in a manner that easily goes unnoticed. Remaining blind to these covert forms of sexism and oppression ensures their survival in society. While the series has a very large audience to consider, including ABC's parent company, Disney, they also have a certain responsibility to their viewers to challenge the oppressive status quo. In a society where binge-watching television series is now considered normal, we should continue to encourage critical consumption of media. This study is just one example of why it is essential to look beneath the surface of a message that is being communicated, especially when that message is communicated weekly to millions of viewers. 


\section{REFERENCES}

ABC. (n.d.) About Once Upon a Time. ABC. Retrieved from http://abc.go.com/shows/onceupon-a-time/about-the-show.

Adalian, J. (2011). Once Upon a Time is a rare hit with the whole family. Vulture. Retrieved from http://www.vulture.com/2011/11/once-upon-a-time-is-a-rare-hit-with-the-wholefamily.html.

Anne, V. (2013). Once Upon a Time stars Jennifer Morrison and Lana Parrilla stick up for SwanQueen fandom. AfterEllen. Retrieved from http://www.afterellen.com/tv/206372once-upon-a-time-stars-jennifer-morrison-and-lana-parrilla-stick-up-for-the-swanqueenfandom.

Bandura, A. (2001). Social cognitive theory of mass communication. Mediapsychology, 3(1), 265-299.

Banet-Weiser, S. \& Portwood-Stacer, L. (2006). "I just want to be me again!” Beauty pageants, reality television, and post-feminism. Feminist Theory, (7)2, 255-272. doi: $10.1177 / 1464700106064423$

Bearman, S., Korobov, N., \& Thorne, A. (2009). The fabric of internalized sexism. Journal of Integrated Social Sciences, 1(1), 10-47.

Bell, E. (1995). Somatexts at the Disney shop: Constructing the pimentos of women's animated bodies. In Bell, E., Haas, L., \& Sells, L. (Eds.) From mouse to mermaid: The politics of film, gender, and culture. (pp. 140-207). Bloomington, IN: Indiana University Press

Bell, E., Haas, L., \& Sells, L. (1995). From mouse to mermaid: The politics of film, gender, and culture. Bloomington, IN: Indiana University Press 
Boylan, C. (Writer), Thomsen, D. T. (Writer), \& Amiel, J. (Director). (2013). Good form [Television series episode]. In Kitsis, E. (Producer) \& Horowitz, A. (Producer), Once Upon a Time. Vancouver, British Colombia: ABC Studios

Boylan, C. (Writer), Thomsen, D. T. (Writer), \& Goddard, A. (Director). (2013). Save Henry [Television series episode]. In Kitsis, E. (Producer) \& Horowitz, A. (Producer), Once Upon a Time. Vancouver, British Colombia: ABC Studios

Brockus, S. (2004). Where magic lives: Disney's cultivation, co-creation, and control of America's cultural objects. The International Journal of Media and Culture, 2(4), 101211. doi: 10.1207/s15405710pc0204_1

Burke, K. (1969). A rhetoric of motives (Vol. 111). Oakland, CA: University of California Press. Burke, S. (2013). What Once Upon a Time does for feminism. Vancouver Observer. Retrieved from http://www.vancouverobserver.com/blogs/feminista/what-once-upon-time-doesfeminism-spoiler-alert

Butler, J. (2006). Gender trouble. New York, NY: Routledge Classics

Campbell, J. (1973). The hero with a thousand faces. Princeton, NJ: Princeton University Press

Campbell, J. (1991). The power of myth. New York, NY: Anchor

Carretero-González, M., \& Rodríguez-Martín, M. E. (2009). Wicked Women: The Menace Lurking Behind Female Independence. At the Interface: Probing The Boundaries, 57, 199-209.

Chambliss, A. (Writer), Chun, T. (Writer), \& Hemecker, R. (Director). (2015). The bear and the bow [Television series episode]. In Kitsis, E. (Producer) \& Horowitz, A. (Producer), Once Upon a Time. Vancouver, British Colombia: ABC Studios. 
Chambliss, A. (Writer), Goldberg, I. (Writer), \& White, V. (Director). (2011). The shepherd [Television series episode]. In Kitsis, E. (Producer) \& Horowitz, A. (Producer), Once Upon a Time. Vancouver, British Colombia: ABC Studios.

Chambliss, A. (Writer), Hales, B. (Writer), \& Duncan, R. (Director). (2016). Dark waters [Television series episode]. In Kitsis, E. (Producer) \& Horowitz, A. (Producer), Once Upon a Time. Vancouver, British Colombia: ABC Studios.

Chambliss, A. (Writer), Horgan, D. (Writer), \& Tirone, R. (Director). (2015). The price [Television series episode]. In Kitsis, E. (Producer) \& Horowitz, A. (Producer), Once Upon a Time. Vancouver, British Colombia: ABC Studios.

Chambliss, A. (Writer), Horgan, D. (Writer), \& Underwood, R. (Director). (2016). A bitter draught [Television series episode]. In Kitsis, E. (Producer) \& Horowitz, A. (Producer), Once Upon a Time. Vancouver, British Colombia: ABC Studios.

Chambliss, A. (Writer), Horgan, D. (Writer), \& Underwood, R. (Director). (2017). Ill-bonding patterns [Television series episode]. In Kitsis, E. (Producer) \& Horowitz, A. (Producer), Once Upon a Time. Vancouver, British Colombia: ABC Studios.

Cheu, J. (2013). Diversity in Disney films: Critical essays on race, ethnicity, gender, sexuality, and disability. Jefferson, NC: McFarland \& Company, Inc.

Coppock, V., Haydon, D., \& Richter, I. (1995). The illusions of 'post-feminism': New women, old myths. New York, NY: Routledge.

Cuklanz, L. M., \& Moorti, S. (2006). Television's "new" feminism: Prime-time representations of women and victimization. Critical Studies in Media Communication, 23(4), 302-321. doi:10.1080/07393180600933121 
Dellinger-Pate, C. \& Aden, R. C. (1999). "More power!”: Negotiating masculinity and femininity in Home Improvement. In Myers, M. (Ed.) Mediated women. (pp. 153-164). Cresskill, NJ: Hampton Press

Dewan, P. (2016). Perennially Popular: The Appeal of Classic Fairy Tales for Children. Children and Libraries, 14(2), 27-31.

Distasio, C. (2014). 6 things you should never say to a Once Upon a Time fan or you'll have to face the Evil Queen. Bustle. Retrieved from https://www.bustle.com/articles/34722-6things-you-should-never-say-to-a-once-upon-a-time-fan-or-youll-have.

Espenson, J. (Writer) \& Cheylov, M. (Director). (2012). Skin deep [Television series episode]. In Kitsis, E. (Producer) \& Horowitz, A. (Producer), Once Upon a Time. Vancouver, British Colombia: ABC Studios

Espenson, J. (Writer) \& Edwards, P. (Director). (2011). That still small voice [Television series episode]. In Kitsis, E. (Producer) \& Horowitz, A. (Producer), Once Upon a Time. Vancouver, British Colombia: ABC Studios

Espenson, J. (Writer) \& Hemecker, R. (Director). (2013). The miller's daughter [Television series episode]. In Kitsis, E. (Producer) \& Horowitz, A. (Producer), Once Upon a Time. Vancouver, British Colombia: ABC Studios.

Espenson, J. (Writer) \& Hemecker, R. (Director). (2015). Siege perilous [Television series episode]. In Kitsis, E. (Producer) \& Horowitz, A. (Producer), Once Upon a Time. Vancouver, British Colombia: ABC Studios.

Espenson, J. (Writer) \& Hemecker, R. (Director). (2016). Heartless [Television series episode]. In Kitsis, E. (Producer) \& Horowitz, A. (Producer), Once Upon a Time. Vancouver, British Colombia: ABC Studios. 
Espenson, J. (Writer) \& Tirone, R. (Director). (2015). Nimue [Television series episode]. In Kitsis, E. (Producer) \& Horowitz, A. (Producer), Once Upon a Time. Vancouver, British Colombia: ABC Studios.

Espenson, J. (Writer) \& Underwood, R. (Director). (2012). Red-handed [Television series episode]. In Kitsis, E. (Producer) \& Horowitz, A. (Producer), Once Upon a Time. Vancouver, British Colombia: ABC Studios.

Espenson, J. (Writer) \& Waxman, M. (Director). (2012). Desperate souls [Television series episode]. In Kitsis, E. (Producer) \& Horowitz, A. (Producer), Once Upon a Time. Vancouver, British Colombia: ABC Studios.

Espenson, J. (Writer) \& Zakrzewski, A. (Director). (2013). Quite a common fairy [Television series episode]. In Kitsis, E. (Producer) \& Horowitz, A. (Producer), Once Upon a Time. Vancouver, British Colombia: ABC Studios.

Espenson, J. (Writer), Goodman, D. H. (Writer), \& Cheylov, M. (Director). (2012). An apple red as blood [Television series episode]. In Kitsis, E. (Producer) \& Horowitz, A. (Producer), Once Upon a Time. Vancouver, British Colombia: ABC Studios.

Feasey, R. (2008). Masculinity and popular television. Edinburgh, UK: Edinburgh University Press.

Feministing. (2012). Once Upon a (feminist) Time. Feministing. Retrieved from http://feministing.com/2012/01/19/once-upon-a-feminist-time/

Fisher, W. R. (1984). Narration as a human communication paradigm: The case of public moral argument. Communications Monographs, 51(1), 1-22.

Fisher, W. R. (1985). The narrative paradigm: An elaboration. Communications Monographs, 52(4), 347-367. 
Foucault, M. (1978). The history of sexuality: An introduction. New York, NY: Random House, Inc.

Genz, S. \& Brabon, B. A., (2009). Postfeminism: Cultural texts and theories. Edenborough, UK: Edenborough University Press.

Glascock, J. (2015). Effect of verbally aggressive television programming on viewers' selfreported verbal aggression. Communication Research Reports, 32(4), 367-372. doi: $10.1080 / 08824096.2015 .1089850$

Goldberg, I. (Writer), Chambliss, A. (Writer), \& Barrett, D. (Director). (2013). Welcome to Storybrooke [Television series episode]. In Kitsis, E. (Producer) \& Horowitz, A. (Producer), Once Upon a Time. Vancouver, British Colombia: ABC Studios

Goldberg, I. (Writer), Chambliss, A. (Writer), \& Spicer, B. (Director). (2012). Fruit of the poisonous tree [Television series episode]. In Kitsis, E. (Producer) \& Horowitz, A. (Producer), Once Upon a Time. Vancouver, British Colombia: ABC Studios

Goodman, D. H. (Writer) \& White, D. (Director). (2012). What happened to Frederick [Television series episode]. In Kitsis, E. (Producer) \& Horowitz, A. (Producer), Once Upon a Time. Vancouver, British Colombia: ABC Studios.

Goodman, D. H. (Writer), Chambliss, A. (Writer), \& Tirone, R. (Director). (2016). Only you [Television series episode]. In Kitsis, E. (Producer) \& Horowitz, A. (Producer), Once Upon a Time. Vancouver, British Colombia: ABC Studios.

Goodman, D. H. (Writer), Hales, B. (Writer), \& Woods, K. (Director). (2017). Page 23 [Television series episode]. In Kitsis, E. (Producer) \& Horowitz, A. (Producer), Once Upon a Time. Vancouver, British Colombia: ABC Studios. 
Goodman, D. H. (Writer), Hull, R. (Writer), \& Solomon, D. (Director). (2013). Think lovely thoughts [Television series episode]. In Kitsis, E. (Producer) \& Horowitz, A. (Producer), Once Upon a Time. Vancouver, British Colombia: ABC Studios.

Goodman, D. H. (Writer), Schwartz, J. (Writer), \& Egilsson, E. (Director). (2015). Birth [Television series episode]. In Kitsis, E. (Producer) \& Horowitz, A. (Producer), Once Upon a Time. Vancouver, British Colombia: ABC Studios.

Goodman, D. H. (Writer), Schwartz, J. (Writer), \& Hemecker, R. (Director). (2015). The broken kingdom [Television series episode]. In Kitsis, E. (Producer) \& Horowitz, A. (Producer), Once Upon a Time. Vancouver, British Colombia: ABC Studios.

Goodman, D. H. (Writer), Schwartz, J. (Writer), Egilsson, E. (Director), \& Hemecker, R. (Director). (2014). Smash the mirror [Television series episode]. In Kitsis, E. (Producer) \& Horowitz, A. (Producer), Once Upon a Time. Vancouver, British Colombia: ABC Studios.

Hay, R. \& Baxter, C. (2014). Happily never after: The commodification and critique of fairy tale in ABC's Once Upon a Time. In Greenhill, P. \& Rudy, J. T. (Eds.), Channeling wonder. (pp. 316-335). Detroit, MI: Wayne State University Press

Hemmings, C. (2011). Why stories matter: The political grammar of feminist theory. London, UK: Duke University Press

Henke, J. B., Umble, D. Z., Smith, N. J. (1996). Construction of the female self: Feminist readings of the Disney Heroine. Women's Studies in Communication, 19(2), 229-249. doi: 10.1080/07491409.1996.11089814 
Henson, L., \& Parameswaran, R. E. (2008). Getting real with "Tell it like it is" talk therapy: Hegemonic masculinity and the Dr. Phil show. Communication, Culture, \& Critique, 1, 287-310.

Hoerrner, K. L. (1996). Gender roles in Disney: Analyzing behaviors from Snow White to Simba. Women's Studies in Communication, 19(2), 213-228. doi: 10.1080/07491409.1996.11089813

Horgan, D. (Writer), Chun, T. (Writer), \& Tirone, R. (Director). (2015). The broken heart [Television series episode]. In Kitsis, E. (Producer) \& Horowitz, A. (Producer), Once Upon a Time. Vancouver, British Colombia: ABC Studios.

Hull, R. (Writer) \& Hemecker, R. (Director). (2014). The tower [Television series episode]. In Kitsis, E. (Producer) \& Horowitz, A. (Producer), Once Upon a Time. Vancouver, British Colombia: ABC Studios.

Hull, R. (Writer), Vasquez, K. (Writer), \& Hemecker, R. (Director). (2013). Selfless, brave, and true [Television series episode]. In Kitsis, E. (Producer) \& Horowitz, A. (Producer), Once Upon a Time. Vancouver, British Colombia: ABC Studios

Jung, C. (2014). Archetypes and the collective unconscious. Princeton, NJ: Princeton University Press

Kluch, Y. (2015). 'The man your man should be like': Consumerism, patriarchy and the construction of twenty-first-century masculinities in 2010 and 2012 Old Spice campaigns. Interactions: Studies in Communication \& Culture, 6(3), 361-377.

Kirsh, S. J. (2006). Cartoon violence and aggression in youth. Aggression and Violent Behavior, 11(6), 547-557. 
Kitsis, E. (Writer), Horowitz, A. (Writer), \& Barrett, D. M. (Director). (2011). The heart is a lonely hunter [Television series episode]. In Kitsis, E. (Producer) \& Horowitz, A. (Producer), Once Upon a Time. Vancouver, British Colombia: ABC Studios.

Kitsis, E. (Writer), Horowitz, A. (Writer), \& Beeman, G. (Director). (2011). The thing you love most [Television series episode]. In Kitsis, E. (Producer) \& Horowitz, A. (Producer), Once Upon a Time. Vancouver, British Colombia: ABC Studios.

Kitsis, E. (Writer), Horowitz, A. (Writer), \& Buckley, N. (Director). (2011). Street rats [Television series episode]. In Kitsis, E. (Producer) \& Horowitz, A. (Producer), Once Upon a Time. Vancouver, British Colombia: ABC Studios.

Kitsis, E. (Writer), Horowitz, A. (Writer), \& Egilsson, E. (Director). (2016). The savior [Television series episode]. In Kitsis, E. (Producer) \& Horowitz, A. (Producer), Once Upon a Time. Vancouver, British Colombia: ABC Studios.

Kitsis, E. (Writer), Horowitz, A. (Writer), \& Gierhart, B. (Director). (2014). The snow queen [Television series episode]. In Kitsis, E. (Producer) \& Horowitz, A. (Producer), Once Upon a Time. Vancouver, British Colombia: ABC Studios

Kitsis, E. (Writer), Horowitz, A. (Writer), \& Hemecker, R. (Director). (2012). 7:15 AM [Television series episode]. In Kitsis, E. (Producer) \& Horowitz, A. (Producer), Once Upon a Time. Vancouver, British Colombia: ABC Studios

Kitsis, E. (Writer), Horowitz, A. (Writer), \& Hemecker, R. (Director). (2013). Heart of the truest believer [Television series episode]. In Kitsis, E. (Producer) \& Horowitz, A. (Producer), Once Upon a Time. Vancouver, British Colombia: ABC Studios 
Kitsis, E. (Writer), Horowitz, A. (Writer), \& Horder-Payton, G. (Director). (2015). Swan song [Television series episode]. In Kitsis, E. (Producer) \& Horowitz, A. (Producer), Once Upon a Time. Vancouver, British Colombia: ABC Studios

Kitsis, E. (Writer), Horowitz, A. (Writer), \& Mylod, M. (Director). (2011). Pilot [Television series episode]. In Kitsis, E. (Producer) \& Horowitz, A. (Producer), Once Upon a Time. Vancouver, British Colombia: ABC Studios.

Kitsis, E. (Writer), Horowitz, A. (Writer), \& Tirone, R. (Director). (2015). Dreamcatcher [Television series episode]. In Kitsis, E. (Producer) \& Horowitz, A. (Producer), Once Upon a Time. Vancouver, British Colombia: ABC Studios.

Kitsis, E. (Writer), Horowitz, A. (Writer), \& Underwood, R. (Director). (2015). The dark swan [Television series episode]. In Kitsis, E. (Producer) \& Horowitz, A. (Producer), Once Upon a Time. Vancouver, British Colombia: ABC Studios.

Kitsis, E. (Writer), Horowitz, A. (Writer), \& White, D. (Director). (2012). The stable boy [Television series episode]. In Kitsis, E. (Producer) \& Horowitz, A. (Producer), Once Upon a Time. Vancouver, British Colombia: ABC Studios.

Kitsis, E. (Writer), Horowitz, A. (Writer), \& White, D. (Director). (2012). A land without magic [Television series episode]. In Kitsis, E. (Producer) \& Horowitz, A. (Producer), Once Upon a Time. Vancouver, British Colombia: ABC Studios.

Kitsis, E. (Writer), Horowitz, A. (Writer), \& White, D. (Director). (2016). An untold story [Television series episode]. In Kitsis, E. (Producer) \& Horowitz, A. (Producer), Once Upon a Time. Vancouver, British Colombia: ABC Studios. 
Kitsis, E. (Writer), Horowitz, A. (Writer), Tirone, R. (Director), \& Hemecker, R. (Director). (2015). Operation mongoose [Television series episode]. In Kitsis, E. (Producer) \& Horowitz, A. (Producer), Once Upon a Time. Vancouver, British Colombia: ABC Studios.

Kuykendall, L., \& Sturn, B. (2007). We Said Feminist Fairy Tales, Not Fractured Fairy Tales!. Children \& Libraries: The Journal of the Association for Library Service to Children, 5(3), 38-41.

Lacroix, C. (2004). Images of animated others: The orientalization of Disney's cartoon heroines from The Little Mermaid to The Hunchback of Notre Dame. The International Journal of Media and Culture, 2(4), 213-229. doi: 10.1207/s15405710pc0204_2

McNay, L. (1992). Foucault and feminism: Power, gender and the self. Boston, MA: Northeastern University Press

Masters, M. (2011). Pilot preview: Jennifer Morrison says Lost fans will love ABC's Once Upon a Time. TVLine. Retrieved from https://tvline.com/2011/04/16/jennifer-morrison-onceupon-a-time.

Masters, M. \& Mitovich, M. W. (2011). Real truths behind ABC's Once Upon a Time (including that pesky Fables comparison). TVLine. Retrieved from https://tvline.com/2011/08/07/5real-truths-once-upon-a-time.

Mills, S. \& Mullany, L. (2011). Language, gender and feminism: Theory, methodology and practice. New York, NY: Routledge

Mitovich, M. W. (2016). Ratings: ABC's Sunday slate goes low. TVLine. Retrieved from http://tvline.com/2016/10/24/once-upon-a-time-ratings-season-6. 
Morgan, C. (2007). Gender role identity crisis on Wisteria Lane: Desperate Housewives as a metaphor for the modern day woman. Florida Communication Journal, 35(2), 112-118.

Mortiz, M. (2004). Old strategies for new texts: How American television is creating and treating lesbian characters. In Carter, C. \& Steiner, L. (Eds.) Critical readings: Media and gender. (pp. 104-122).

Munford, R. \& Waters, M. (2014). Feminism and popular culture: Investigating the postfeminist mystique. New Brunswick, NJ: Rutgers University Press

Murdock, M. (1990). The heroine's journey: Woman's quest for wholeness. New York, NY: Random House, Inc.

Nadal, K. L., Hamit, S., Lyons, O., Weinberg, A., \& Corman, L. (2013). Gender microaggressions: Perceptions, processes, and coping mechanisms of women. In Paludi, M. A. (Eds.) Psychology for business success. (pp. 193-220).

Pallotta, F. (2014). CBS exec: Netflix hasn't had a hit since 2003. CNN. Retrieved from http://money.cnn.com/2014/12/09/media/cbs-netflix-jab/index.html?hpt=hp_t4.

Parrilla, L. [LanaParrilla]. (2017). Thank you @CImpala1967 for this beautiful painting! I absolutely love it!!! \#fanart \#ArtMatters. Retrieved from https://twitter.com/LanaParrilla/status/822118471941038082.

Prieler, M. (2016). Gender stereotypes in Spanish- and English-language television advertisements in the United States. Mass Communication and Society, 19(1), 275-300. doi: 10.1080/15205436.2015.1111386

Putnam, A. (2013). Mean ladies: Transgendered villains in Disney films. In Cheu, J. (Ed.), Diversity in Disney films. (pp. 163-178). Jefferson, NC: McFarland \& Company 
Romano, A. (2013). Fandom uproar ensues after Once Upon a Time actor insults shippers. The Daily Dot. Retrieved from https://www.dailydot.com/parsec/fandom/ouat-shipperstwitter-fight/.

Rowland, R. C. (1990). On mythic criticism. Communication Studies, 41(2), 101-116.

Rozario, R. C. D. (2004). The princess and the Magic Kingdom: Beyond nostalgia, the function of the Disney princess. Women's Studies in Communication, 27(1), 34-59. doi:

10.1080/07491409.2004.10162465

Sattar, S. (2016). The projection of female villains in the "Wonderful World of Disney." Literature and Linguistics. Presented at the 5th Annual International Conference on Language.

Schwabe, C. (2014). Getting real with fairy tales: Magic realism in Grimm and Once Upon a Time. In Greenhill, P. \& Rudy, J. T. (Eds.), Channeling wonder. (pp. 294-315). Detroit, MI: Wayne State University Press

Schwartz, J. (Writer), Fong, L. (Writer), \& Lynch, J. (Director). (2016). I'll be your mirror [Television series episode]. In Kitsis, E. (Producer) \& Horowitz, A. (Producer), Once Upon a Time. Vancouver, British Colombia: ABC Studios.

Siede, C. (2014). Once Upon a Time and Blacklist are the most popular shows on Netflix. AV Club. Retrieved from http://www.avclub.com/article/once-upon-time-and-blacklist-aremost-popular-show-212860.

Stone, K. (1975). Things Walt Disney never told us. Journal of American Folklore, 88(347), 42. doi:10.2307/539184

Tatar, M. (2003). The hard facts of the Grimms' fairy tales. Princeton, NJ: Princeton University Press 
Te'eni-Harari, T. \& Eyal, K. (2015). Liking them thin: Adolescents' favorite television characters and body image. Journal of Health Communication, 20(1), 607-615. doi: $10.1080 / 10810730.2015 .1012241$

Tigelaar, L. (Writer) \& White, D. (Director). (2011). Snow falls [Television series episode]. In Kitsis, E. (Producer) \& Horowitz, A. (Producer), Once Upon a Time. Vancouver, British Colombia: ABC Studios.

Tsay-Vogel, M. \& Schwartz, M. L. (2013) Theorizing parasocial interactions based on authenticity: The development of a media figure classification scheme. Psychology of Popular Media Culture, 3(2), 66-78. doi: 10.1037/a0034615

van Zoonen, L. (1994). Feminist Media Studies. London, UK: Sage Publications.

Vogler, C. (1985). A practical guide to Joseph Campbell's the hero with a thousand faces. Hero's Journey. Retrieved from http://www.thewritersjourney.com/hero's_journey.htm.

Ward, A.R. (2002) Mouse morality: The rhetoric of Disney animated film. Austin, TX: University of Texas Press

Weber, B. R. (2006). What makes the man? Television makeovers, made-over masculinity, and male body image. International Journal of Men's Health, 5(3), 287.

Wells-Lassagne, S. (2015). Divided loyalties: opening sequences in small-screen fantasy adaptations. Screen, 26(2), 269-275. 


\section{APPENDIX: CHARACTER DESCRIPTIONS}

\section{Emma Swan}

- Played by Jennifer Morrison

- Relationships

○ Mother of Henry Mills

- Daughter of Mary Margaret/Snow White and David Nolan/Prince Charming

- Sister of baby Neal

○ Girlfriend of Killian Jones/Captain Hook

- Arcs

○ Arc 1 - Controlling Magic

- Season 4A

- Arc 2-Dark One

- Season 5A

\section{Henry Mills}

- Played by Jared Gilmore

- Relationships

- Biological son of Emma Swan and Baelfire "Bae"

- Adopted son of Regina Mills/The Evil Queen

○ Grandson of Mary Margaret/Snow White, David Nolan/Prince Charming, and Mr.

Gold/Rumplestiltskin

- Arcs

- Arc 1 - Truest Believer

- Season 3A

- Arc 2 - The Author

- Season 4B

- Season 5B

Mary Margaret/Snow White

- Played by Ginnifer Goodwin

- Relationships

$\circ$ Wife of David Nolan/Prince Charming

- Mother of Emma Swan and baby Neal

- Grandmother of Henry Mills

- Daughter of King Leopold and Queen Eva

- Stepdaughter of Regina Mills/The Evil Queen

- Arcs

- Arc 1 - Introduction

- Season 1A

- Arc 2-Dark Snow White

- Season 2B

\section{David Nolan/Prince Charming}

- Played by Josh Dallas

- Relationships 
- Husband of Mary Margaret/Snow White

$\circ$ Father of Emma Swan and baby Neal

- Twin of Prince James (whose identity he assumes after James' death)

- Grandfather of Henry Mills

- Arcs

○ Arc 1 - Introduction

- Season $1 \mathrm{~A}$

- Arc 2 - Fearful Charming

- Season 3, Episode 14

\section{Regina Mills/The Evil Queen}

- Played by Lana Parrilla

- Relationships

○ Adoptive mother of Henry Mills

- Stepmother to Mary Margaret/Snow White

○ Widow of King Leopold

- Daughter of Cora and Henry Mills

- Sister of Zelena

- Arcs

- Arc 1 - Introduction

- Season 1

- Arc 2-Regina vs Evil Queen

- Season 6A

\section{Mr. Gold/Rumplestiltskin}

- Played by Robert Carlyle

- Relationships

- Father of Baelfire "Bae"

- Grandfather of Henry Mills

- Husband of Belle French

- Son of Peter Pan

- Arcs

- Arc 1 - Introduction

- Season 1A

- Arc 2 - "Hero" Rumplestiltskin

- Season 5A 